\title{
Patara Liman Hamamı: Mimarisi ve Yapı Evrelerine Dair İlk Gözlemler
}

\author{
Harbour Bath of Patara: \\ First Observations About Building Phases and Architecture
}

\author{
Serap ERKOÇ*
}

Öz: Antik kentte Roma Dönemi'ne tarihlendirilen dört hamam yapısından (Liman Hamamı, Nero Hamamı, Merkez Hamam ve Küçük Hamam) birisi olan Liman Hamamı kentin kuzeydoğusunda konumlanmaktadır. Yapı, işlevleri bakımından birbirleri ile ilişkili bir dizi mekânın, düz bir hat üzerinde kullanım sırasına uygun olarak yerleştirilmesi ile oluşturulmuştur. Doğudan batıya doğru, birbiri ardına sıralanan ve frigidariumtepidarium-caldarium olarak adlandırdığımız bu mekânlar yapının çekirdek kısmını oluşturur. Yapı, zaman içinde ortaya çıkan intiyaçlar doğrultusunda yeni eklemelerle kompleks bir oluşuma doğru gelişim göstermiştir. Bu bağlamda çekirdeği meydana getiren üç mekândan (frigidarium, tepidarium ve caldarium) frigidarium'un doğusuna, Bazilika thermarum olarak tespit ettiğimiz diğer bir mekân eklenmiştir. Bu büyük mekânın doğusunda ise henüz sınırları tespit edilememiş mozaik bir zemin yer alır. Yapının kuzey, batı ve güney cepheleri büyük kireçtaşı bloklarla döşeli caddeler ile sınırlandııımıştır. Bu çalışma ile bahsi geçen bu yapı kompleksinin planı, inşa tekniği ve mekânları detaylı olarak tanıtılacak, en önemlisi de yapıda tespit edilen dört yapı evresinden söz edilecektir.

Anahtar sözcükler: Lykia, Patara, Limam Hamamı, Bazilika Thermarum

Abstract: The Harbour Baths, one of the four bathing structures (Harbour Baths, Nero Baths, Central Baths and Small Baths) in the ancient city that were dated to the Roman Period, is located to the northeast of the city. The comple was constructed by placing a series of functionally interrelated units on a straight line according to their order of use. Having been lined up in tandem from west to east, these units, namely frigidarium, tepidarium and caldarium, constitute the core section of the building. The building evolved into a comple construction with new annees due to arising requirements in time. In that contet, another unit, the so called Basilica thermarum, was added to the east of this core section (frigidarium, tepidarium, and caldarium). There is a mosaic floor, the boundaries of which haven't been determined yet, to the east of that large unit. The northern, western, and southern fronts of the building were constrained by roads paved with large limestone blocks. The present study provides detailed information on the plan, construction technique, and units of the building and most importantly, the four phases of construction as observed in the building are to be addressed.

Keywords: Lycia, Patara, Harbour Baths, Basilica Thermarum

* Dr. Öğr. Ü., Anadolu Üniversitesi, Edebiyat Fakültesi, Arkeoloji Bölümü, Klasik Arkeoloji Anabilim Dalı, Eskişehir.seraperkoc@anadolu.edu.tr 


\section{Yapının Kent İçindeki Konumu ve Önemi}

Antik kentte Roma Dönemi'ne tarihlendirilen dört hamam yapısından (Liman Hamamı, Nero Hamamı, Merkez Hamam ve Küçük Hamam) birisi olan Liman Hamamı ${ }^{1}$ kentin kuzeydoğusunda, Tepecik diye adlandırılan coğrafi yükseltinin güney eteğinde konumlanmaktadır (Fig. 1).

Yapı batısında yer alan ve Datça Hurması olarak bilinen Anadolu kökenli hurma ağaçlarından dolayı modern literatürde sıklıkla Hurmalık Hamamı ${ }^{2}$ olarak anılmıştır. Ayrıca kentin kuzeyinde konumlanmış olmasından hareketle Kuzey hamamı olarak da söz edilmiştir ${ }^{3}$. Tarafımızca, kentteki konumunu ve öncelikli inşa amacını daha iyi vurguladığı için Liman Hamamı tanımlaması tercih edilmiştir. Yapı, iç limanın hemen doğusundaki konumu ile özellikle kente gelen tüccarlar ve denizciler için hiç kuşkusuz özel bir öneme sahipti. Ancak bunun dışında hamamın; "Patara halkı tarafından yaptırılan" ve üzerinde imparator Traianus ve eşi Plotina ile onun LykiaPamphylia Valisi C. Trebonius Procolus Mettius Modestus ve yakınlarını onurlandıran yazıtların da bulunduğu kent kapısının 60 m güneybatısında yer alması, kente sadece deniz yolu ile gelenler için değil, aynı zamanda kuzeyden yani karadan giriş yapanlar için de hizmet vermiş olduğunu göstermektedir.

\section{Yapının Planı, İnşa Tekniği ve Mekânları}

Yapı işlevleri bakımından birbirleri ile ilişkili bir dizi mekânın, düz bir hat üzerinde kullanım sırasına uygun olarak yerleştirilmesi ile oluşturulmuştur. Doğudan batıya doğru, birbiri ardına sıralanan ve frigidarium-tepidarium-caldarium olarak adlandırdığımız mekânlar yapının çekirdek kısmını oluşturur.

1 Yapıda 1989 yıllarında başlayan çalışmalar belirli aralıklarla 1997 yılına kadar devam etmiştir, bk. Işık 1992, 236; Çevik 1993, 393-394.; Bulba - Kızgut 1995, 286-287.; Çevik - Kızgut 1995, 255-256; Kızgut - Özhanlı 1996, 165-166; Kızgut et al. 1997, 199-200; Kızgut 1999, 159-160; Işık 1999, 477-493; Işık 2000.

2005 - 2008 yılları arasında Feriştah Alanyalı’nın yürütücülüğünde frigidarium'un doğu, tepidarium'un batı yarısı, caldarium'un içi ve kuzey cephesinde, ayrıca yapının kuzey ve güney cephelerinde çalışmalar yapılmıştır. Bu çalışmaların sonuçları için bk. Alanyalı-Soykal - Şen 2007, 412-430; Alanyalı 2009, 117-144; bu zaman aralığında ele geçen Kuzey Afrika kökenli seramikler D. Şen Yıldırım tarafından bir yayına dönüştürülmüştür: Şen - Yıldııım 2012, 151-171. Arkeolojik kazı ve belgeleme çalışmaları 2010 yılından itibaren Serap Erkoç ve Mustafa Koçak yönetiminde sürdürülmektedir. Bu dönem çalışmaları için bk. Erkoç-Akca 2012, 18-20; Erkoç 2013, 173; Erkoç 2014, 275; Erkoç 2015, 239-251; Erkoç - Koçak 2015, 97; Erkoç - Aktaş 2016, 64 - 67; Erkoç - Koçak 2018, 103-114. Bu zamana kadar ele geçen sikkelerin bir bölümü, ş. Özüdoğru tarafından "Patara Sikke Basımları ve Patara Kazılarından (1989-2001) Ele Geçen Sikkeler" konulu Akdeniz Üniversitesinde hazırlanmış, basılmamış yüksek lisans tezinde incelemiştir, bk. Özüdoğru 2000. Liman Hamamı, bölge genelinde ya da kent özelinde hamam yapıları ile ilgili çalışmalara da konu edilmiştir: F. Yegül, 1992 yılı yayınının Lykia hamamları bölümünde yapıya kısaca değinmiştir, bk. Yegül 1992. A. Farrington, Lykia Hamamları'nı konu alan 1995 yılı yayınında yapıdan söz eder. Ancak kitabın yazıldığı yıllar yapının henüz çok az kısmı açığa çıkarıldığından verilen bilgilerde eksiklikler ve hatalar mevcuttur, bk. Farrington 1995. A. Farrington'un, J. J. Coulton ile birlikte kaleme aldıkları makalede Lykia hamamlarındaki ısıtma sistemi ve bu sistem içerisinde kullanılan pişmiş toprak çivilerden bahsedilirken yapıdan söz edilmiştir, bk. Farrington - Coulton 1990, 57-67. T. Korkut, 2003 yılındaki makalesinde Patara'daki dört hamam yapısını mimari acıdan birbirleri ile karşılaştırarak bilgiler vermiş, ayrıca ısıtma sistemlerine de değinmiştir, bk. Korkut 2003, 445-459. F. Gülşen'in 2007 yılı çalışmasında da yine Patara'daki hamamların yapım tekniklerinden ve ısıtma sistemlerinden söz edilmiştir, bk. Gülşen 2007, 453-470.

2 Çevik - Kızgut 1995, 255-256; Kızgut - Özhanlı 1996, 165-166; Kızgut et al. 1997, 199-200; Korkut 2003, 445-459; Alanyalı-Soykal - Şen 2007, 412-430; Gülşen 2007, 453-470; Alanyalı 2009, 117-144; Korkut 2003, 445-459; Gülşen 2007, 453-470.

3 Farrington 1995, 158 No. 41 / Res. 18. 


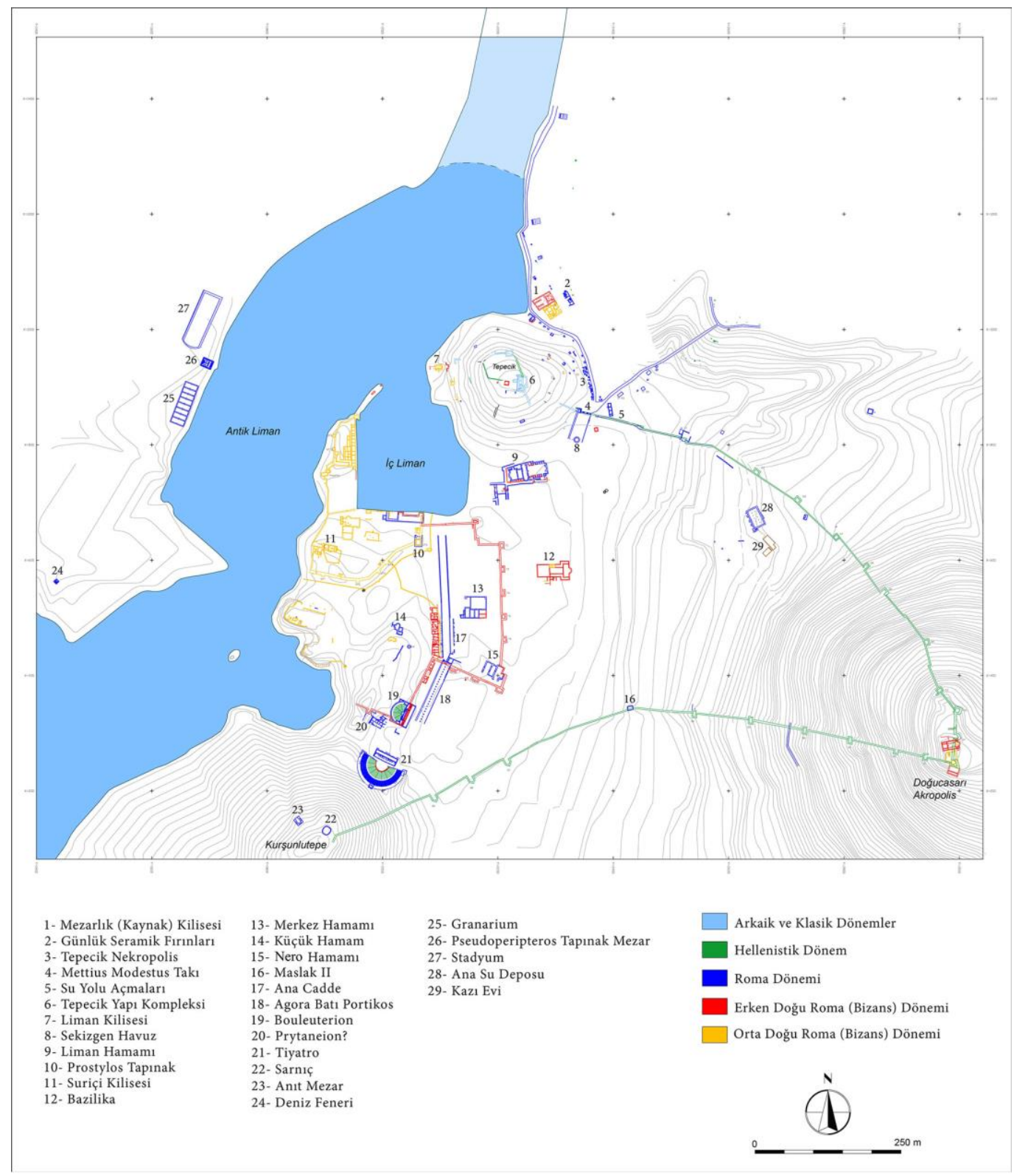

Fig. 1. Patara Kent Planı (Patara Kazı Arşivi)

Plan, ısıtılmamış alanlardan ısıılıan alanlara (frigidarium, tepidarium ve caldarium) doğru ilerleyişi ve bunun tam tersi bir düzen içinde geri dönüşü yansıtmaktadır (Fig. 2). Arkeolojik literatürde bu plan şeması, "Tek Eksenli Dizi Tipi" olarak değerlendirilir". Yapı, zaman içinde ortaya çıkan intiyaçlar doğrultusunda yeni eklemelerle kompleks bir oluşuma doğru gelişim göstermiştir. Bu bağlamda çekirdeği meydana getiren üç mekândan (frigidarium, tepidarium ve caldarium) frigidarium'un doğusuna, Bazilika thermarum olarak tespit ettiğimiz diğer bir mekân eklenmiştir.

Roma hamamlarının genelinde karşılaşıldığı gibi yapının sıcak mekânları güneş ışığını ve ısısını en uzun süre alacağı şekilde doğu-batı aksına yerleştirilmiştir. Çevresinde bu ışığı kesecek

4 İşlevsellik ve yapısallık, ısının kontrolü ve ziyaretçi dolanımının yönetimi bakımından bu tarz bir planlama duyarlı ve etkin bir kullanım sağlamaktadır. Bu tip ve onun çok sayıdaki varyasyonu Roma Imparatorluğu'nun hemen her coğrafyasında yaygındır, bk. Yegül 2006, 60 - 61. 
ya da kendisini gölgede bırakacak herhangi bir yüksek yapının varlığı bilinmemektedir. Kuzey, batı ve güney cepheleri büyük kireç taşı plakalarla döşeli caddelerle sınırlandırılmaktadır. Batı ve güney caddeleri, hamamın güneybatı köşesinde bir kavşak oluştururlar. Güneydeki cadde iç limana doğru ilerlerken, batıdaki kent merkezine doğru uzanır.

Hamamının konumlandığı arazi, batıdan doğuya ve kuzeyden güneye doğru eğimlidir. Bu nedenle, antik dönem yürüme seviyesi bağlamında örneğin doğu ile batı uçlar arasında 1.3 metrelik bir kod farkı bulunmaktadır. Benzer şekilde, kuzeydeki caddeden yapıya giriş düzayakken, güneyde birkaç basamaklı bir merdivenle sağlanır.

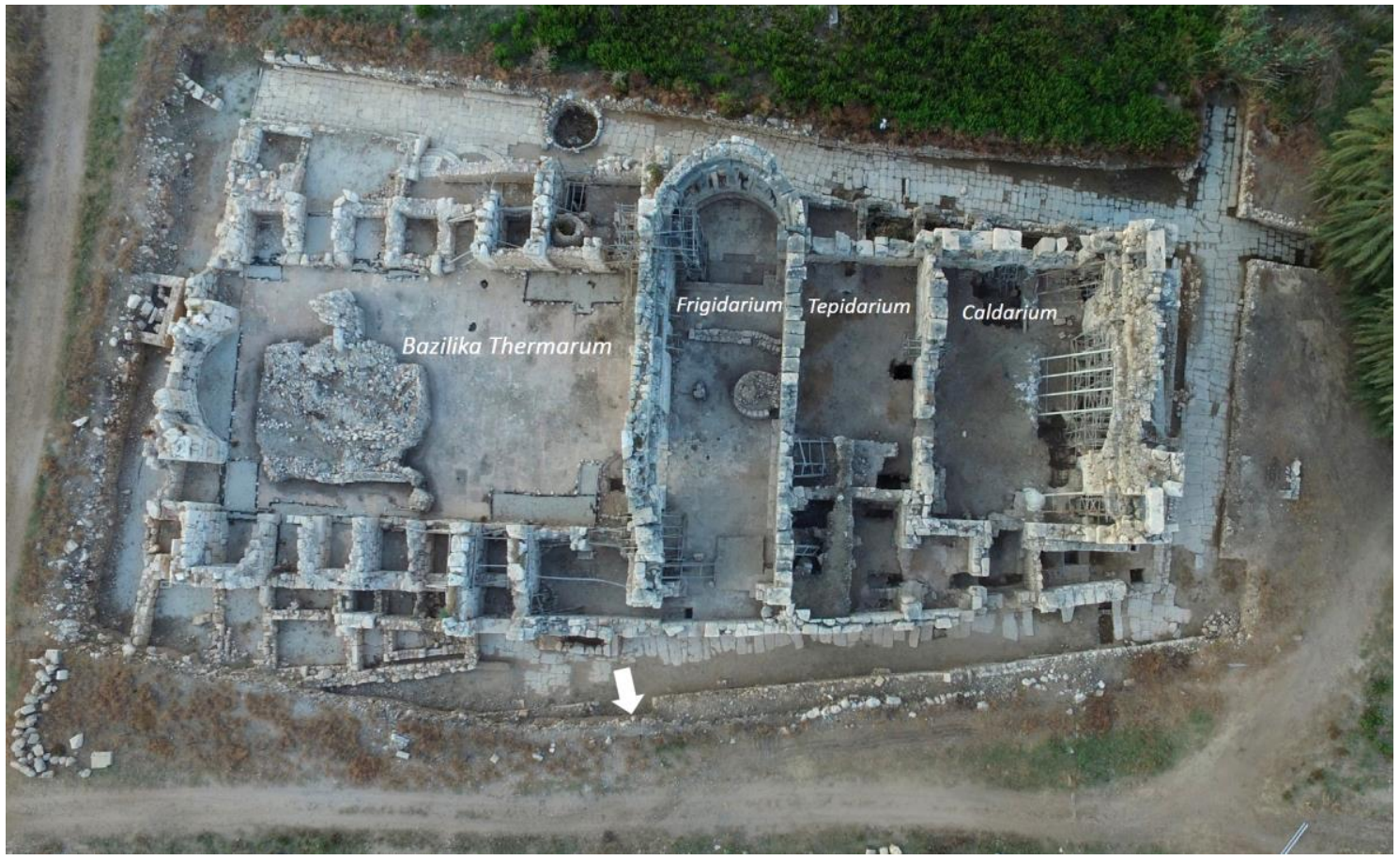

Fig. 2. Liman Hamamı

Yerel kireç taşından çeşitli ölçülerde bloklar, en yoğun kullanılan yapı elemanlarıdırlar. Bunların yanı sıra yine çeşitli boylarda kırma taşlar hem duvarlarda dolgu hem de kimi mekânların üst örtüsünün (beşik tonoz) asal malzemesi olarak kullanılmıştır. Yapının çoğu yerinde pişmiş toprak tuğla kullanımı da mevcuttur; özellikle hypokaust sisteminin neredeyse tamamı, praefurnium'lar, tepidarium'da olduğu gibi kimi bölme duvarları, hamamı güneybatıda çevreleyen küçük mekânlar ve koridorların tonozlu üst örtüleri ve de bazilika thermarum'un tüm tonozları tuğla kullanılarak inşa edilmiştir. Yapı elemanlarının birbirlerine tutturulması çoğu yerde harçla sağlanırken, kenet kullanımı sadece duvar kaplamalarında gözlemlenmektedir. Görülebildiği kadarıyla duvar ve taban kaplamaları çeşitli türlerde mermer, açık renkte kireç taşı levhalar ve mozaikle gerçekleştirilmiştir.

Son evreye varana kadar hamamın hemen tüm duvarlarında harç ve kırma taştan oluşan bir dolgu içeren çift cidarlı yapım tekniği uygulanmıştır. Yalnızca bazilika thermarum'un bazı duvarlarında kırma taştan kuru duvarlara rastlanmaktadır.

\subsection{Frigidarium}

Yapının doğusunda yer alan, yaklaşık 29.33 x 7.50 m ölçülerine sahip bu mekân, tüm yapının en iyi korunmuş bölümüdür. Kalın duvarları, yer yer beşik tonozun oturduğu üzengi seviyesini de aşacak şekilde korunmuştur. Sadece çatısı yerinde değildir. Ayrıca doğu duvarın kuzey bölümüyle batı duvarın ortalarında biraz daha geniş çaplı eksiklikler gözlemlenir. Neredeyse tamamen 
kaybolmuş diğer unsurlar ise yer döşemesi ile duvar kaplamalarıdır. Sadece bir kaç noktada in situ mermer döşeme ve duvar diplerindeki birkaç noktada kaplama kalıntılarına rastlanır.

Kazılar sırasında mekânda çok sayıda ve hayli büyük boyutlarda, kırma taş ve harç kullanılarak yapılmış tonoz parçasına rastlanılmıştır. Ayrıca doğu ve güney duvarın en üst seviyesinde tonozun duvar üzerine oturtulan kısımları korunmuş durumdadır. Bu bulgu ve buluntuların gösterdiği gibi, mekânın üstü küçük kırma taşlar ve harçtan meydana gelen bir beşik tonoz ile örtülmüştür.

Mekânın güneyini, yapının tüm gövdesinden dışa taşan bir apsis oluşturur. Buraya yerleştirilen ve büyük bir kısmı apsis içinde kalan, $42 \mathrm{~m}^{2 \prime}$ lik piscina (soğuk su havuzu) ile frigidarium'da yaklaşık $250 \mathrm{~m}^{2}$ lik bir kullanım alanı ortaya çıkmaktadır.

Frigidarum'un doğu cephesinden girişi sağlayan toplam dört kapı mevcuttur. Bunlardan ikisi cephenin kuzey yarısında yer alır ve kemerlidir ${ }^{5}$ (Kapı I ve II); güney yarısında daha dar olanlar ise (Kapı III ve IV) düzdür ${ }^{6}$. Bunlara ilaveten duvarın en kuzeyinde, bazilika thermarumla ilişkiyi sağlayan bir geçiş (dar bir koridor) daha bulunur. Batı duvarın güney yarısında tepidarium'a açılan iki kapı (Kapı V ve VI) ${ }^{7}$ yer alır. Aynı duvarın kuzey yarısında kenarları pilasterlerle süslenmiş ve sudatorium'a geçiş sağlayan bir kapının daha (Kapı VII) ${ }^{8}$ varlığı tespit edilmiştir (Fig. 3). Ancak lento kısmı ciddi bir tahribat görmüş olan bu kapı, geç bir dönemde moloz taşlar ile kapatılarak iptal edilmiştir. Bu duvarın kuzey ucunda yine sudatorium'a açıldığı düşünülen bir kapı daha yer almaktadır.

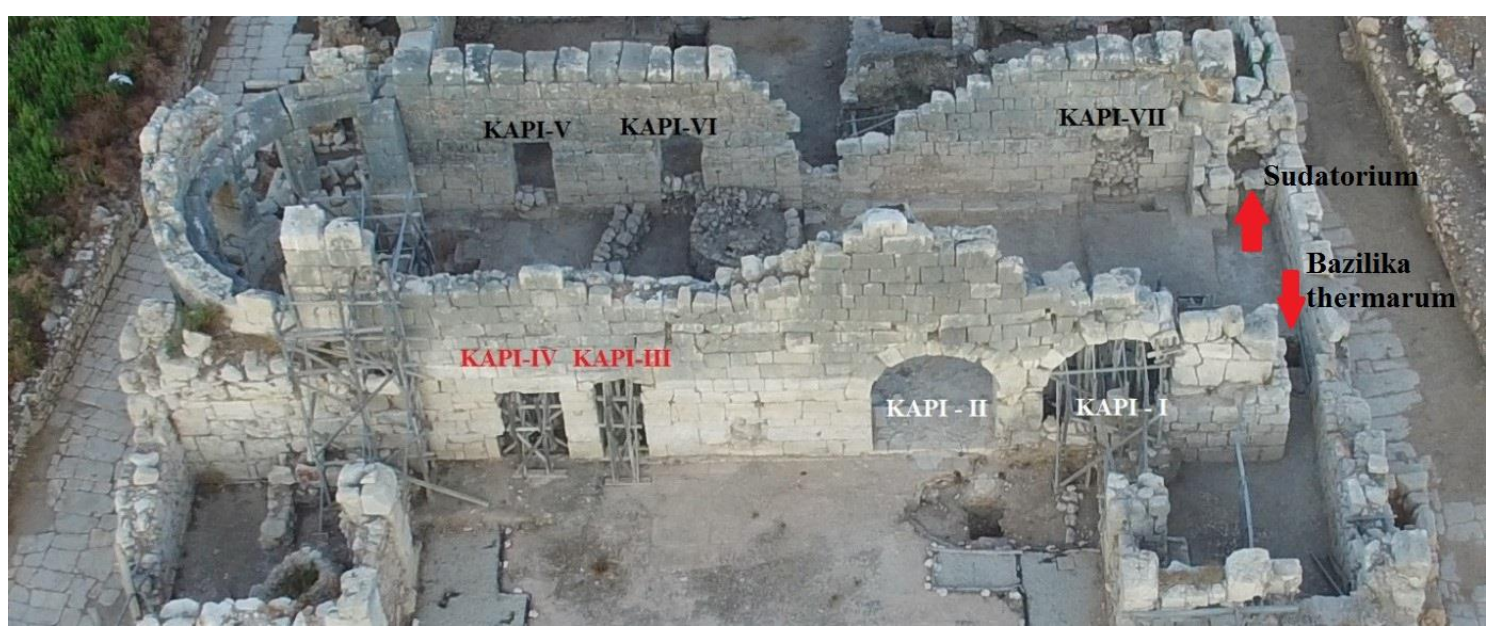

Fig. 3. Frigidarium-Kapılar

\subsubsection{Apsis ve Piscina}

Frigidarium'un güney ucuna yerleştirilen ve tüm yapı gövdesinin dışına taşan apsis, bu mekânı hamamın neredeyse en alımlı bölümlerinden biri haline getirmiştir. Apsislerle biten, çatısı tonozlu dikdörtgen mekânlar genellikle küçük ve orta boy hamamlarda yaygın olarak kullanım bulmuştur ${ }^{9}$. Bu yapıda da apsis, mekânın hem içinde hem de dışında form olarak vurgulanmıştır.

\footnotetext{
Doğu duvarın kuzey yarısındaki kemerli Kapı I: 3.66 × 3.26 × 1.48 m; Kapı II: 3.84 × 3.24 × 1.48 m ölçülerindedir. Kapı III: $2.88 \times 1.20 \times 1.48$ m; Kapı IV: $2.88 \times 1.82 \times 1.48$ m.

Kapı V ve VI: 1.24 m açıklığa sahiptir. Her iki kapı geç dönemde tuğla ve taşlarla örülmüş, böylece orijinal şekillerine dair izler büyük oranda kaybolmuştur.

Kapı VII: 1.17 x 1.90 m ölçülerindedir.

9 Apsisli cepheler Anadolu’nun güney ve güneybatı bölgesindeki hamamlarda (Oinoanda, Kadyanda, Pınara, Tlos ve Arykanda) yaygın olarak görülür, bk. Farrington 1995. Ayrıca Tlos-Büyük Hamam için bk. Korkut 2015a, 53-59; Korkut 2015b, 30-32.
} 
Apsis duvarında her biri 2.5 m yüksekliğe ve 1.30 m genişliğe sahip altı adet pencere açıklığı bulunur $^{10}$ (Fig. 4). Pencerelerin aralarında birer adet konsol, duvara aplike edilmiştir. Bunlardan sadece iki tanesi kırık halde günümüze kalabilmiştir ${ }^{11}$. Aynı şekilde pencere payeleri üzerinde de konsollar aplike edilebilmek için açılmış kare oyuklar bulunmaktadır (Fig. 5). Tüm bu konsolların üzerinde muhtemelen heykeller durmaktaydı ancak bunlarla ilişkili olarak herhangi bir buluntuya rastlanılmamıştır.

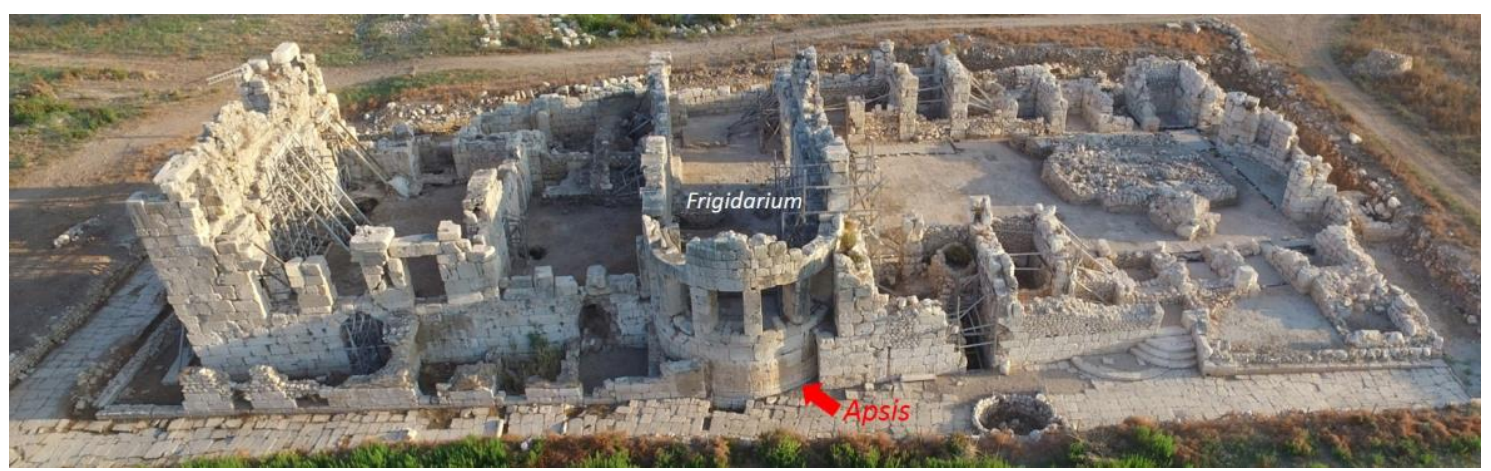

Fig. 4. Frigidarium-Apsis

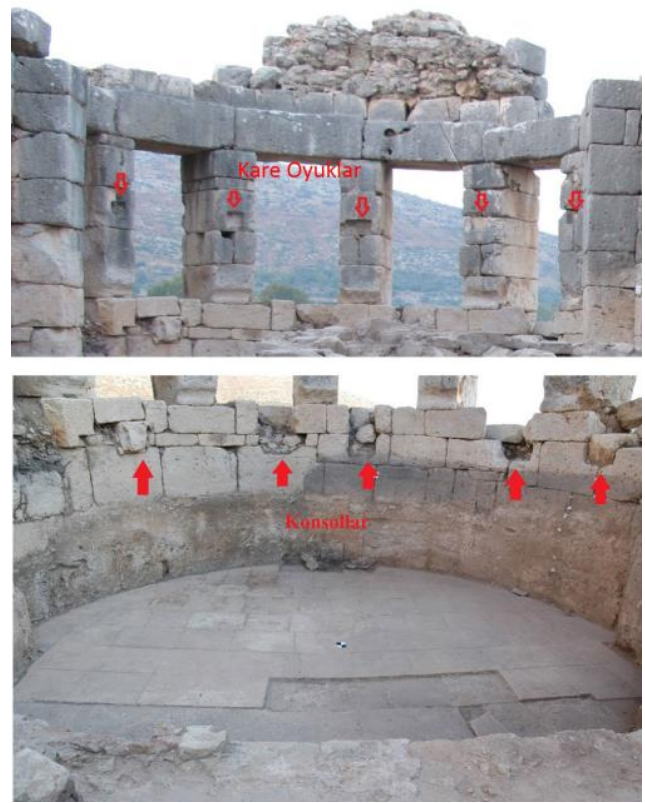

Fig. 5. Frigidarium-Apsis/Konsol ve Kare Oyuklar

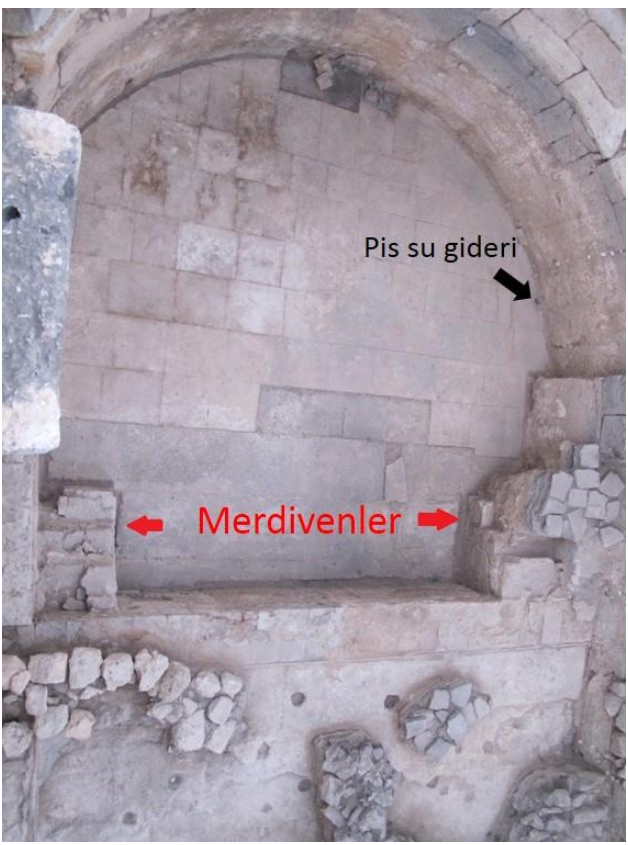

Fig. 6. Frigidarium-Piscina

Apsis zeminini tamamen kaplayacak şekilde, pencerelerin hemen önüne yarım daire planlı bir piscina yerleştirilmiştir (Fig. 6). 7.34 × 6.13 m ölçülerindeki bu soğuk su havuzu frigidarium'dan fazla yüksek olmayan, orijinalinde dış mermerle kaplı tuğla bir duvar ile ayrılmıştır. Frigidarium'da, doğu duvarın güney ucundaki kapının önünde tespit edilen mermer levhalı eşiğin hemen önünde hamamın orijinal tabanı korunmuştur. Bu durumda havuz, frigidarium'un zemininden

10 Maalesef kazılarda pencere sistemine ait hiçbir buluntu ele geçmemiştir. Ancak Roma Dönemi`nden itibaren bu tür pencerelerde tuğladan pencere pervazlarının kullanıldığı bilinmektedir. Anadolu'da buna, geç bir örnek olmakla birlikte en güzel örneğe Laodikeia Kilisesi'nde rastları, bk. Şimşek 2015, 52-53 / Res. 68-73.

11 Konsollardan bir tanesi, frigidarium'un güney yarısında olasılıkla MS V. yüzyıl sonrasında yapılmış duvarda yapı malzemesi olarak kullanılmıştır. 
$10 \mathrm{~cm}$ yüksekte başlamakta ve bu seviyeden $1.00 \mathrm{~m}$ aşağıda son bulmaktadır. Yani havuzun toplam derinliği yaklaşık $1.1 \mathrm{~m}$ 'dir.

Havuza hem doğu hem de batıdan üçer basamaklı merdivenlerle inilmektedir. Basamaklar, 2 cm kalınlığında ince gri damarlı beyaz renkli mermer levhalarla kaplıdır. Kireçtaşı levhalarla oluşturulmuş havuzun zemini kuzeybatıya doğru eğimlidir, zira havuzun $12 \mathrm{~cm}$ çapındaki su gideri bu tarafa yerleştirilmiştir. Havuzun temiz su ihtiyacı ise apsis duvarının dış tarafında bir kısmı in situ olarak günümüze ulaşan künkler ve kurşun borular vasıtasıyla karşılanmıştır.

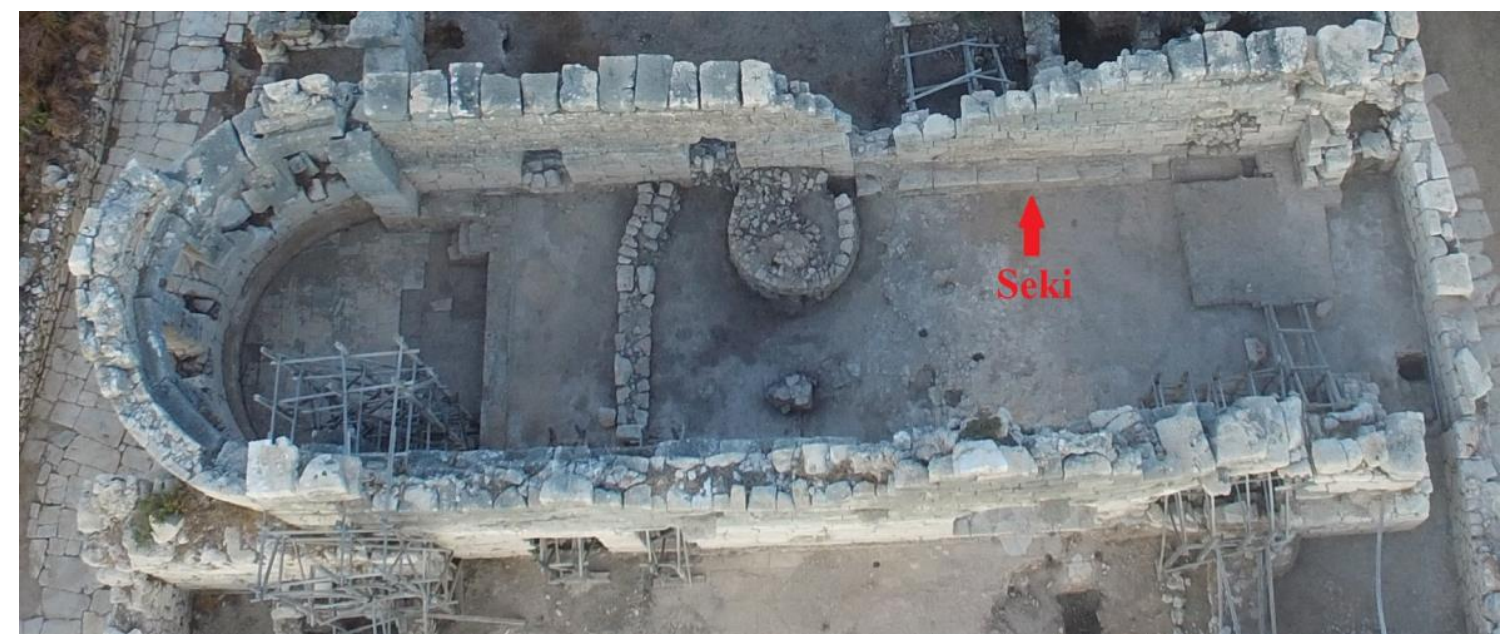

Fig. 7. Frigidarium-Seki

\subsubsection{Seki}

Frigidarium'un batı duvarı önünde yaklaşık 5.8 m uzunluğunda, birden fazla blok taşın yan yana yerleştirilmesi ile oluşturulmuş bir seki dikkati çeker (Fig. 7). Frigidarium'un doğu duvarındaki kemerli girişlerin tam karşısına denk gelen bu seki, olasılıkla insanların oturup soyundukları ve giyindikleri apodytreium'un bir parçasıdır. Esasında bu tip sekilerin hemen üzerindeki duvarda, hamam ziyaretçilerinin eşyalarını yerleştirebilmeleri için ahşap dolapların olması gerektiği bilinmektedir. Ancak sözü edilen sekinin üzerindeki duvarın büyük bir bölümünün yıkılmış olması böylesi bir izi takip edebilmemize imkân tanımamıştır. Diğer taraftan bu sekinin güneye doğru sonlandığı noktada duvarın yaklaşık 1.2 m genişliğinde bir bölümünün tuğlalarla örülerek kapatıldığı gözlemlenir. Benzer bir oluşum tam karşıdaki duvarda da mevcuttur. Bu bulgu akla frigidarium'un, şimdilik hangisi olduğunu bilmediğimiz bir evresinde bölünmüş olabileceğini getirir. Fakat önümüzdeki, yapının hamam olarak kullanıldığı son evrede artık bu "bölme" yoktur, zira tuğla örgü üzerinde duvar kaplama levhalarının metal kenet kalıntıları halen görülebilmektedir.

\subsection{Tepidarium}

Frigidarium'un batısında yer alan tepidarium'un korunmuşluk düzeyi frigidarium'a benzer (Fig. 2). Mekânda tespit edilen kopmuş ve çökmüş şekildeki tonoz parçaları burasının da üst örtüsünün tıpkı frigidarium gibi beşik tonoz olduğunun anlaşılmasına imkân tanımıştır.

$15.5 \times 8.1$ m'lik bir ölçüye sahip tepidarium'un güney cephesinde üç adet dikdörtgen pencere bulunur. Buradan 1.3 m genişliğinde 2.9 m yüksekliğinde iki adet kapı caldarium'a açıır. Mekânın altındaki hypokaust sistemi, zeminin ciddi anlamda çökmesine neden olduğundan döşemeye dair bilgiler yetersizdir. Ancak köşelerdeki harç kalıntıları bu mekânın da tıpkı frigidarium gibi mermer kaplı olması gerektiğini düşündürmektedir. 


\subsubsection{Isıtma Sistemi}

Yapının bu bölümü hem yerden hem de duvardan ısıtma sistemine sahiptir. Batı duvarı önünde gerçekleştirilen sondaj (Sond. 6/16) çalışmalarında hypokaust sistemine dair bilgiler elde edilebilmiştir. Yan yana sıralanan tuğla payeler (pilae) birbirine $55 \mathrm{~cm}$ mesafede yerleştirilmişlerdir. Mevcut yükseklikleri 1.09 m olan payeleri oluşturan tuğlalar 55 × $28 \times 5 \mathrm{~cm}$ ölçülerindedir. Her bir tuğla arasında yaklaşık 2.5 ya da 3 cm kalınlığında harç tabakası mevcuttur (Fig. 8).

Duvardan Isıtma sisteminde terrakotta çiviler kullanılmıştır. Mekânın özellikle güney yarısında hem batı hem de doğu duvarda terrakotta çivilerin yerleştirildiği kare yuvalar hala görülebilmektedir (Fig. 9); çivilerin uzunluğu 18.5-25 cm arasında değişmektedir. Çivilerin gövdesi yuvarlak, uç kısımları ise genelde dikdörtgen şeklindedir. Kazılar sırasında ele geçen çiviler, canlı kırmızı, kırmızımtırak, sarı ve hatta kahverengiye uzanan dört farklı renk varyasyonuna sahiptir. Yuvaların içine yerleştirilen çivilerin etrafı harç ile doldurulmaktadır. Bunlar, tabandan yukarıya doğru önlerine yerleştirilen pişmiş toprak levhaları tutarak duvarla bu levhalar arasında bir boşluk oluş-

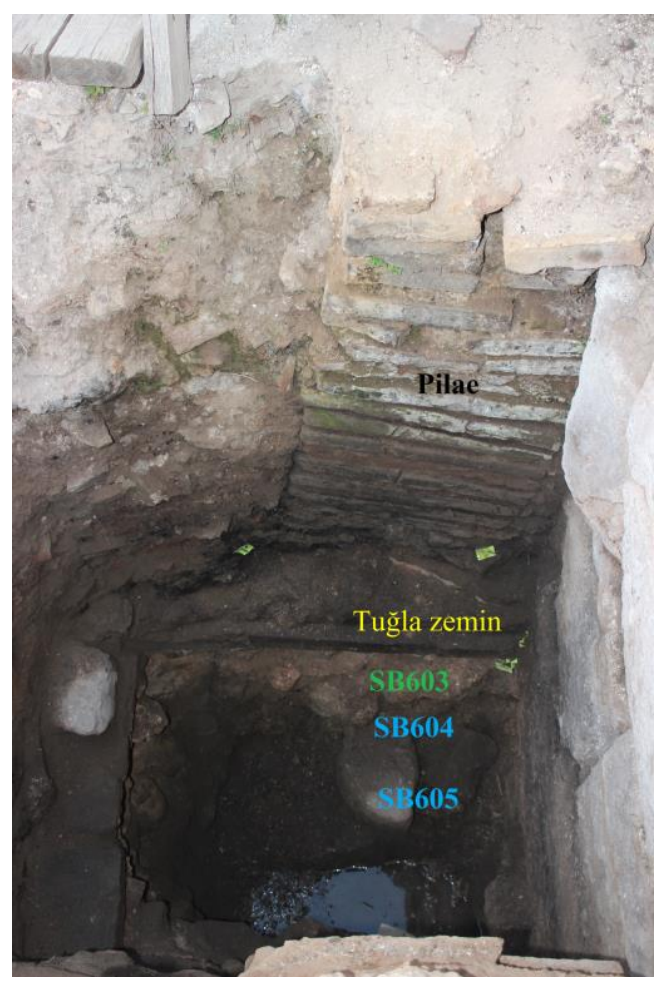

Fig. 8. Tepidarium-Pilae masını sağlarlar. Pişmiş toprak levhaların üzeri ise mermer levhalar ile kaplanmıştır. Bu boşluk, zemin altındaki hypokaust ile bağlantılıdır; dolayısıyla mekân hem yerden hem de duvardan ısıtıımış olur. Mekânın doğu duvarının güney duvar ile birleştiği köşede atık gazların çıkmasını sağlayan baca deliği yer almaktadır. Kare yuvaların etrafındaki küçük kenet yuvaları ise mermer plakaların duvara sabitlenmesi içindir.

\subsubsection{Havuz ve praefurnium}

Tepidarium'un güney duvarında pencerelerin hemen altında yer alan kalın bir harç tabakası dikkat çekicidir. Sözü edilen bu harç tabakası zeminde de dikdörtgen bir çerçeve oluşturmaktadır. Her ne kadar ciddi anlamda hasar görmüş olsa da kalıntılardan bu alanda bir sıcak su havuzunun varlığı tespit edilmiştir. Zira havuzunun bağlı olduğu güney duvarına dıştan bir de praefurnium eklenmiştir. Ama bu praefurnium ve sıcak su havuzu yapıya ilk evresinden sonraki bir evrede eklenmiş olmalıdır, zira yapının orijinal blokları traşlanıp kırılarak açılmıştır (Fig. 10).

\subsubsection{Kuzey Yarı, Tuğla Duvar ve Sudatorium}

Tepidarium'un kuzey sınırını oluşturan tuğla duvar, alttaki büyük blok taşların üzerinde yükselmektedir. Hem bu blok taşlar, hem de üzerine muhtemelen daha sonradan eklenen tuğla duvar tepidarium'un batı duvarı ile hiçbir organik bağ göstermez. Bu tespit tepidarium'un kuzeyini sınırlandıran bu tuğla örgünün buraya sonradan ilave edilmiş olabileceğini gösterir (Fig. 11). Bu tuğla duvar ile altındaki blok taşların önüne $55 \mathrm{~cm}$ arayla yerleştirilmiş olan hypocaust sistemine ait 3 adet tuğla paye (pilae) görülmektedir. Payeler 18-23 cm çapında küçük taşlardan döşenmiş bir taban üzerinde yer almaktadır. Bu anlamda buradaki tuğla payeler mekânın güney yarısındakiler ile işçilik anlamında farklılıklar sunar. Bu durum her iki yarıdaki hypokaust sisteminin dönemsel olarak da birbirinden farklı zamanlarda yapıldığını göstermektedir. 


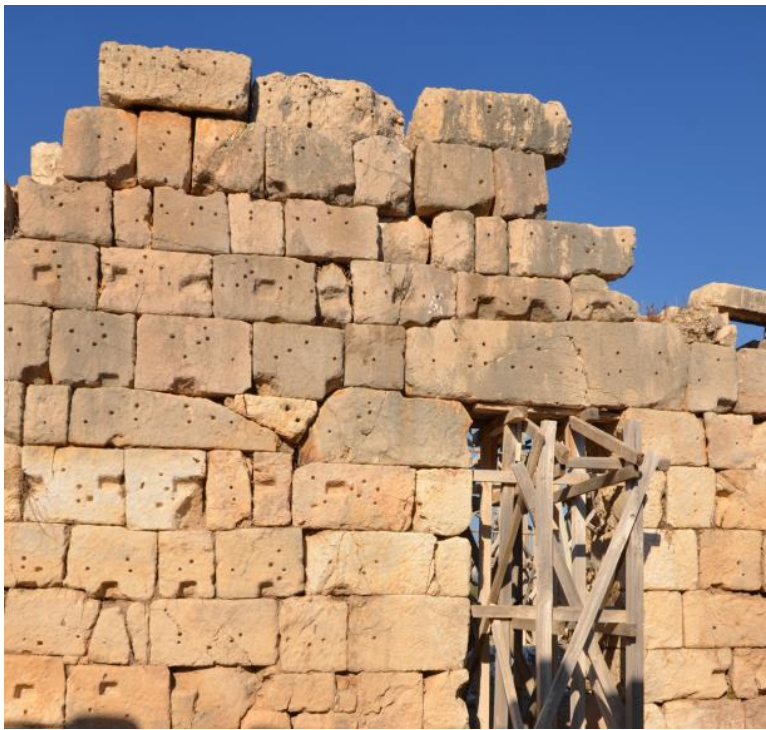

Fig. 9. Tepidarium-Batı duvar

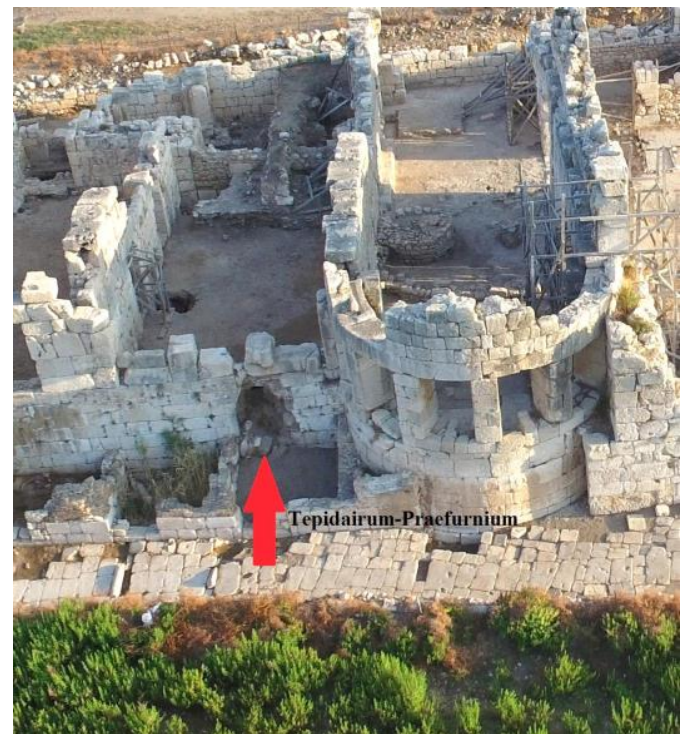

Fig. 10. Tepidarium-Praefurnium

Tepidarium'un kuzey yarısında sözü edilen bu tuğla duvar ile birlikte $7.35 \times 7.40 \mathrm{~cm}$ ölçülerinde kareye yakın bir mekân oluşur (Fig. 11). Taban döşemesi, duvar kaplaması ve çatısı tamamen yok olmuştur. Söz konusu mekân, çekirdek yapının kuzeyine, frigidarium'un kuzeydoğu köşesinden başlayıp caldarium'un kuzeydoğusuna kadar devam eden duvar eklendiğinde oluşmuştur. Tepidarium'un kuzeyine böylece sonradan eklenen bu mekânın işlevi henüz tam olarak bilinmemekle beraber, yerden ısıtma sistemine sahip olması ancak su giderine rastlanmaması ve hamamın sıcak bölümlerine yakınlığı onun sudatorium olabileceğini akla getirir. Dört bir köşedeki payandaların varlığı mekânın üzerinin bir çapraz tonoz ile kapatılmış olduğunu düşündürür. Bu küçük odanın batısında, yine kare planlı $5.20 \times 4.75 \mathrm{~cm}$ ölçülerinde daha küçük bir mekân yer alır. İkisinin arasındaki geçiş hayli geniş olduğundan burada bir kapı olduğu düşünülmemektedir. Bu küçük mekânın batısında, dıştan bir praefurnium bulunmaktadır. Böylece bu iki mekânın ısıtmasının muhtemelen bu praefurnium tarafından sağlandığı söylenebilir. Biraz daha büyüğünde olduğu gibi bu mekânın köşelerinde de çıkıntılı, kimisi tuğlayla örülmüş payeler bulunur; bu da üst örtünün bir çapraz tonoz olduğuna işaret eder.

\subsection{Caldarium}

17.40 x 10.75 m ölçüleri ile kompleksin en batısında konumlanan caldarium, yapının en fazla zarar görmüş mekânıdır (Fig. 2). Mekânın üst örtüsüne dair bilgilerimiz ne yazık ki mevcut değildir. Ancak batı duvar üzerinde kısmen korunan harçlı küçük kırma taşların varlığı, bu mekânın üzerinin de diğer iki mekânda (frigidarium ve tepidarium) olduğu gibi kırma taşlardan yapılmış bir beşik tonoz ile örtülmüş olduğunu ortaya koyar. Güney duvarının, pencerelerden sonra üst kısmı yoktur, daha fazlası bir durum karşıdaki kuzey duvarı için de geçerlidir. Batıdaki büyük kemer ayakta durmakla beraber, hemen üstündeki duvarın iç cidarı yıkılmış durumdadır. İç cephelerindeki kenet delikleri ise duvarların mermer kaplı olduğunun anlaşımasına imkân tanımaktadır. 


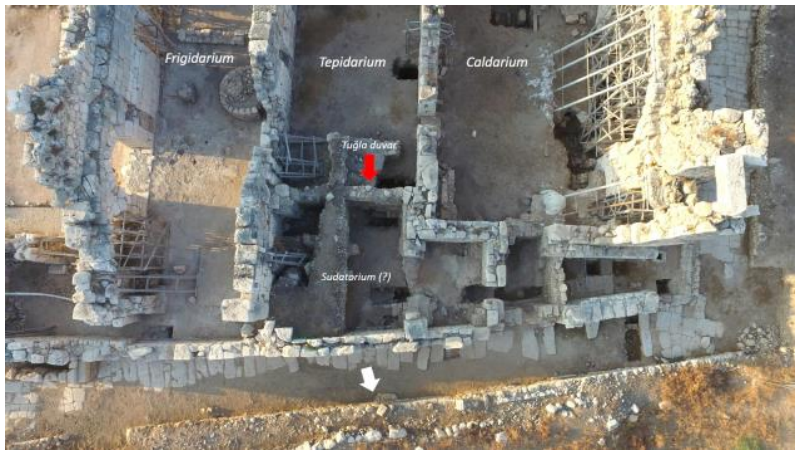

Fig. 11. Tepidairum-Tuğla duvar ve Sudatorium (?)

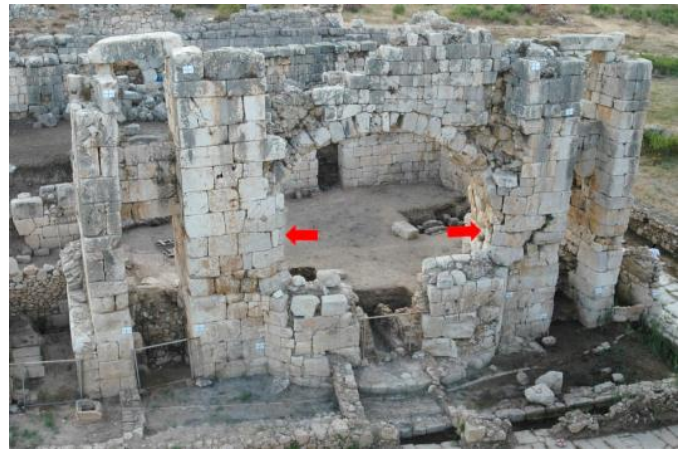

Fig. 12. Caldarium-Batı duvar/Pah'lar

\subsubsection{Duvarlar ve praefurnium'lar}

Mekânın doğu duvarına yerleşik iki kapı, tepidarium'dan buraya geçişi sağlar. En hareketli duvarı $8.50 \mathrm{~m}$ genişliğinde ve $4.40 \mathrm{~m}$ derinliğindeki apsisiyle batıdakidir. Apsisin her iki yanında, yukarıda birer penceresiyle, yüksek açıklıklar söz konusudur. Dış cepheden incelendiğinde, apsisin orijinal evresinde yaklaşık $3 \mathrm{~m}$ yüksekliğe kadar düzgün taşlarla ve yarım daire olarak yükseltildiği, daha sonra ise pah yaptığı anlaşılmaktadır (Fig. 12). Her iki köşede de pahların varlığı buralarda birer pencere açıklığının olduğunu ortaya koymaktadır; bu bulgudan hareketle caldarium apsisi duvarında da, tıpkı frigidarum'da olduğu gibi pencereler bulunduğunu söyleyebiliriz. Ancak bu apsisin diğerinden daha büyük olduğu göz önüne alındığında ya daha fazla sayıda ya da daha geniş pencereler beklenmelidir. Sözü edilen bu alan orijinal evresinde olasılıkla tuğla bir yarım kubbe ile örtülmüş olmalıdır. Zira her iki pahın hemen üst kodunda harçlı tuğla kalıntıları dikkat çekmektedir. Ancak sonraki bir dönemde (ya da yapı evresinde) apsisin iç duvarının apsidal yapısı bozulmuş ve orta kısmı düze yakın şekilde yeniden onarılmıştır. Bu süreçte buraya sıcak su havuzları ile birlikte bir de praefurnium eklenmiştir. Bu değişiklikten sonra pencerelerin durumunun ne olduğunu maalesef bilememekteyiz.

Batı duvardaki apsisin her iki yanındaki pencerelerin hemen altındaki yüksek açıklıkların içerisindeki tuğla kalıntıları buraların da yine ısıtma ve sıcak su sistemiyle ilişkili olduklarını gösterir.

Güney duvarda üç adet pencere yer almaktadır. Bu pencerelere ait herhangi bir buluntu bilinmemektedir. Ortadakinin hemen altında kemerli bir açıklık mevcuttur. Bu kemerli açıklığın içinde de yine bir praefurnium'un varlığı gözlemlenir.

Yapının kuzeyinde dışarıya dil şeklinde uzanan $3.75 \times 2.85 \mathrm{~cm}$ ölçülerinde, zemini tuğla döşemeli, üzeri tuğla tonoz ile kapalı küçük bir açıklık vardır. Olasılıkla hamamın orijinal evresine ait praefurnium olmalıdır. Ancak geç bir dönemde ağız kısmının örülmüş olması, işlevini bu dönemde yitirdiğini göstermektedir.

Bu durumda caldarium'da, beş adet praefurnium bulunmaktadır; birer adet kuzey ve güney yüzlerde, üç adet de batı yüzde yer alır ${ }^{12}$.

\subsubsection{Havuzlar}

Caldarium ilk yapım evresinde iki büyük havuza sahip olmalıdır. Bunlardan ilki kuzey duvarı önünde (olasılıkla boylu boyunca) uzanan bir havuzdur. Halen havuza dair mermer zemin kaplamaları görülebilmektedir. İkincisi ise mekânın güneybatı köşesinde izlenir. Bunun güney duvarı boyunca uzanıp uzanmadığı tespit edilememekle beraber, kuzeydeki havuza paralel

12 Bunların hepsinin aynı dönemde kullanıı kullanılmadığı henüz tespit edilememiştir. 
düşünüldüğünde, beklenebilir bir durumdur. $70 \mathrm{~cm}$ derinliğe ve $1.75 \mathrm{~cm}$ genişliğe sahip havuz, kuzeydekine göre daha iyi korunmuştur. Sözü edilen bu havuzun sularını yeterince ısıtabilmek için batı cephedeki apsisli duvarın her iki yanında alt taraftaki açıklıkların içine ekstra praefurnium’lar yapılmıştır. Zira açıklıklar içindeki tuğla örgüleri bu duruma işaret etmektedir.

Mekânın batısında yer alan apsisin iç kısmına iki adet sıcak su havuzu ve alt tarafa bu havuzların ısıtılması için giriş kısmı batıda olan bir praefurnium eklenmiştir. Havuzların eklendiği dönemde apsisin duvarı ile duvar kaplama levhalarının arasının hiç boşluk bırakmayacak şekilde tuğlalarla örülmüş olduğu görülür. Bu detay teknelerin kullanıldığı dönemde caldarium'da artık duvardan ısıtma sisteminin en azından bu noktada tamamen iptal edildiğini düşündürür.

\subsubsection{Isıtma sistemi}

Mekânın mevcut durumu gözlemlendiğinde hem yerden hem de duvardan ısıtma sistemine sahip olduğu anlaşılır. Hypokaust şöyle oluşturulmuştur: kare, dikdörtgen ya da yuvarlak tuğladan örülmüş payeler, tuğla bir zemin üzerine oturtulmuştur. Bu tuğla örgü payeler özellikle duvar diplerinde yine tuğladan kemerlerle birbirine bağlanmışlardır. Mekânın orta kısmında tuğla payelerin üzerine bipedalesler yerleştirilmiştir. Bunun üzerinde de mekânın zemini yükselmektedir.

Mekânın doğu duvarı üzerindeki kare yuvalar burasının da yine tıpkı tepidarium'da olduğu gibi terrakotta çivilerden meydana gelen duvardan ısıtma sistemi ile de ısıııldığını gösterir. Mekânın güneydoğu köşesinde de bir bacanın varlığı dikkat çeker.

\section{Bazilika thermarum konumu ve işlevi}

Hamamın çekirdek bölümünün (frigidarium-tepidarium-caldarium) doğusunda yer alan ve kazısı yapılana kadar geçen süreçte hamam yapılarının genel düzenlemelerinden hareketle genellikle palaestra olarak adlandırılan bu mekân 2010-2013 yılları arasında açığa çıkarıımıştır. Dıştan dışa yaklaşık 28.60 × 40.00 m. ölçülerindeki bu büyük alanın kuzeyi ve güneyi derin nişlerle sınırlandırımış, doğusu ise apsidal bir duvarla sonlanmıştır (Fig. 2). Mermer zeminli bu yapının kuzeydoğu ve güneydoğu köşeleri ile doğu dış cephesi ise gri, kırmızı ve bej renkli küçük çakıl taşlarından yapılmış mozaik bir zeminle çevrelenmiştir ${ }^{13}$.

Görkemli bir mimariye sahip bu yapının tabanı tümüyle mermer kaplıdır. Bu olgu da yapının bugüne kadar sanıldığı gibi bir palaestra olamayacağının temel göstergelerinden biridir. Anadolu'nun farklı bölgelerindeki kentlerde, örneğin Ephesos'taki Vedius Gymnasiumu ${ }^{14}$, Doğu Hamam Gymnasiumu ${ }^{15}$, Scholastika Hamamları ${ }^{16}$, Alexandria Troas'taki Hamam Gymnasiumu ${ }^{17}$,

13 Kuzey cephedeki 4. nişin hemen arkasındaki mozaik, bir yazıta sahiptir. Epigraflar tarafından yapılan ilk gözlemlere göre MS III. yüzyılın ilk yarısına tarihlendirilen yazıt, mozaiklerin Pataralı bir kişi tarafından yaptırıldığına işaret etmektedir.

14 Palaestra ile batı salonları arasına yerleştirilen mermer salonun hemen arkasındaki geniş " $\mathrm{H}$ " biçimli salon, Steskal tarafından plan tipinden hareketle Bazilika thermarum olarak adlandırılmıştır, bk. Steskal 2003, 235; Ayrıca bk. Steskal - La Torre 2008, 298-299.

15 Yapının kuzey, doğu ve batı kenarları boyunca uzanan ve derin nişlere sahip salon, Bazilika thermarum/ Apodyterium olarak isimlendirilmiştir. Doğu ve batıdakilerin kuzey kenarları apsidal bir duvar ile sonlanmaktadır, bk. Yegül 2006, 245 / Res. 256.

16 Scholastika (Varius) hamamında, frigidarium un güneyine yerleştirilmiş bazilikal planlı mekânın, geniş bir giriş salonu, bir lobi ve apodyterium olarak kullanım görmüş olduğu düşünülmektedir, bk. Yegül 2006, 254 / Res. 276.

17 Yegül tarafından plan ve yapım teknikleri açısından Ephesos'taki Doğu Hamam-gymnasiumu ile yakın benzerlik sunduğu tespit edilen yapının kuzey, güney ve doğu kenarlarında nişlere sahip salonlar yer almaktadır. Kuzey ve güneydekilerin doğu kenarları apsidal bir duvar ile sonlanmaktadır, bk. Yegül 2006, 246-247 / Res. 260. 
Aezanoi'daki Hamam Gymnasiumu ve Perge'deki Güney Kapısı Hamamları ${ }^{18}$ da böylesi mekânlara sahiptir. Genelde palaestra ile frigidarium arasında bir bağlantı sağlayan bu mekânın işlevi ile ilgili olarak yapının içindeki yerleşimine ve büyüklüğüne göre çeşitli önerilerde bulunulmuştur. Bugüne kadar bu mimari yapı tipi için, soyunma odaları, giriş salonları, yürüyüş ve dinlenmek için ayrılmış salonlar, kötü hava koşullarında üzerinin kapalı olmasından hareketle spor aktivitelerinin yapıldığı mekânlar, kentsel-idari ve gösterilere dönük mekân, insanların bir araya gelip sosyalleştikleri, fikir ve sanat eğitimin yapıldığı yerler gibi değişik şekillerde açıklamalar getirilmiştir. İşlevi konusundaki çeşitlilik, mekânın isimlendirmesinde de söz konusudur. L. Crema $^{19}$ ve R. Maccanico ${ }^{20}$, dinlenme ve eğlence yeri olarak düşündükleri bu mekânları ambulacrum olarak isimlendirmişlerdir. A. von Gerkan ve F. Krischen, özel bir isimlendirmede bulunmayıp sadece yıkanma dışında olan uzun salonlar ${ }^{21}$, J. B. Ward-Perkins ${ }^{22}$ ise anıtsal koridorlar olarak tanımlarlar. F. Yegül'ün bildirdiğine göre ise batı ve kuzey Afrika'daki yazılı kaynaklarda bu tip mekânlar bazilika thermarum olarak adlandırılmaktadır ${ }^{23}$. I. Nielsen de bu tip mekânları bazilika thermarum olarak isimlendirmeyi tercih eder ${ }^{24}$. Bu irdelemelerden hareketle Patara Liman Hamamı́nın doğusuna bitişik olarak inşa edilen bu yapının planı, bazilika thermarum olarak tanımlanmasını mümkün kılmaktadır.

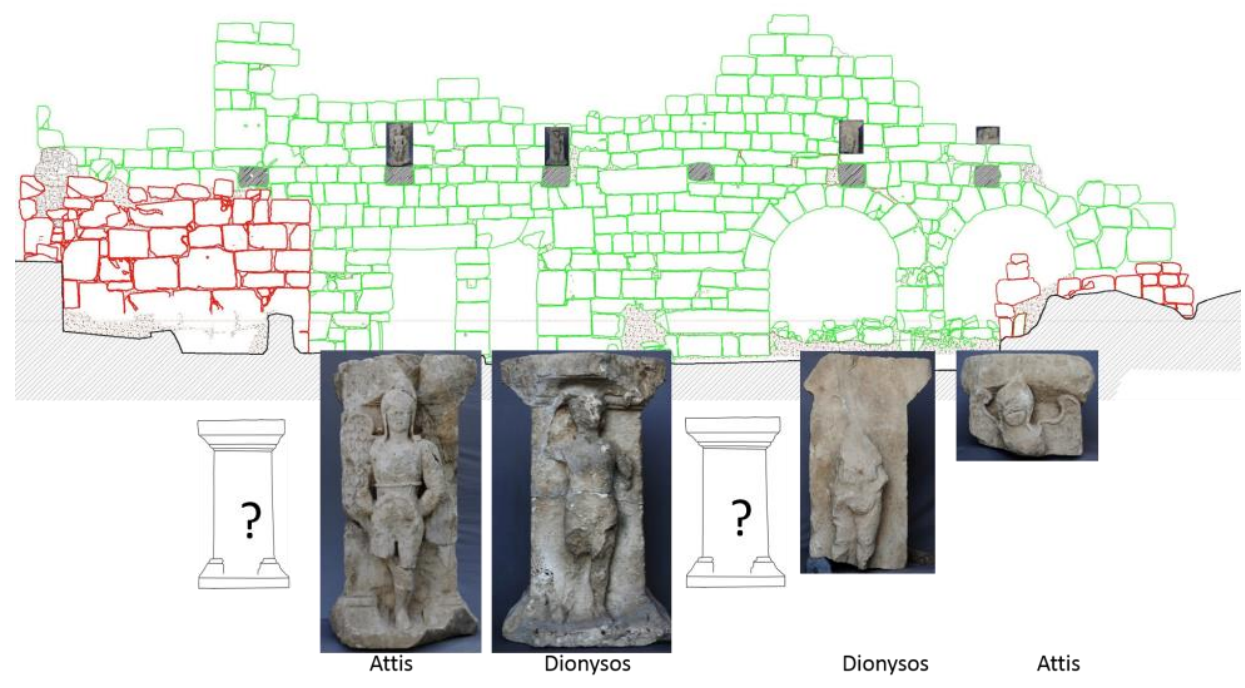

Fig. 13. Frigidarium Doğu duvar-Konsollar ve Postamentler

Yapının işlevine yönelik bulgular, ikinci kullanım evresindeki yoğun kullanım nedeniyle yeterli değildir. Ancak bazilika thermarum'un kazıları sırasında bu mekânla ilişkili olduğu düşünülen plastik eserler tespit edilmiştir. Bunlar; Lenbach tipi bir Herakles ile üzerlerinde Attis ve Dionysos kabartmaları bulunan dört postamenttir ${ }^{25}$. Eserler üzerindeki kenet izleri, bunların bu mekân ile

18

Palaestradan sütunlu bir giriş ile bazilikal planlı salona girilmektedir. 46.80 × 13.40 m ölçülerindeki salonun uzun kenarlarında derin niş/küçük odacıklar yoktur ancak kuzeyi apsidal bir duvar ile sonlanmaktadır. Mozaik zeminli bu mekân Abbasoğlu’na göre fikirsel ve sanatsal eğitimin yapıldığı bir yer olmalıdır. Mekânın Pamphylia'daki diğer hamam yapıları ile karşılaştırması için bk. Abbasoğlu 1982, 103-105. Crema 1959, 409.

Maccanico 1963, 32-60.

21 von Gerkan - Krischen 1928, 94.

22 Ward - Perkins 1981, 292-294.

23 Yegül 2006, 278.

24 Nielsen 1990, 162

25 Postamentlerin tipolojik ve ikonografik değerlendirmesi ve mekân içindeki konumları ile ilgili öneri ve 
frigidarium'un ortak duvarında yer alan konsollar üzerinde durduklarını göstermiştir (Fig. 13). Mekânın doğusunda konumlanan apsidal duvarın iç kesimindeki nişlerin de heykeller için olabileceğini düşünmek yanlış olmayacaktır. Bu irdelemeler doğrultusunda bazilika thermarum olarak isimlendirdiğimiz mermer zeminli, görkemli heykel ve kabartmalarla süslenmiş bu mekânın hem bir reprezentasyon hem de; insanların bir araya gelip tartıştıp-konuştukları, fikir alışverişi yaptıkları bir yer olduğunu düşünmek doğru olacaktır.

\subsection{Bazilika thermarum mimarisi ve çatı sistemi}

Yapının güneydoğu köşesindeki duvarları büyük oranda ve kimi yerlerde taban seviyesine kadar yıkılmıştır. Diğer bölümler genellikle daha iyi korunmuş durumdadır. Duvarları çift cidarlı olup, hamamın çekirdek yapısındakilerden biraz daha küçük boyutlardaki kireç taşlarından örülmüşlerdir. Bazı yerlerde, güney caddeye bakan cephede olduğu gibi, bloklardan oluşturulmuş duvarların araları kırma-moloz taşlarla örülerek doldurulmuştur.

içten içe 32.15 × 17.62 m’lik ölçülere sahip mekânın kuzey ve güneyi; duvar kalınlıkları 1.10 m olan, ancak ölçüleri birbirinden farklııklar gösteren 7 adet derin niş ile çevrelenmiş, doğusu ise her iki yanında yine birer niş bulunan apsidal bir duvar ile sınırlandırılmıştır.

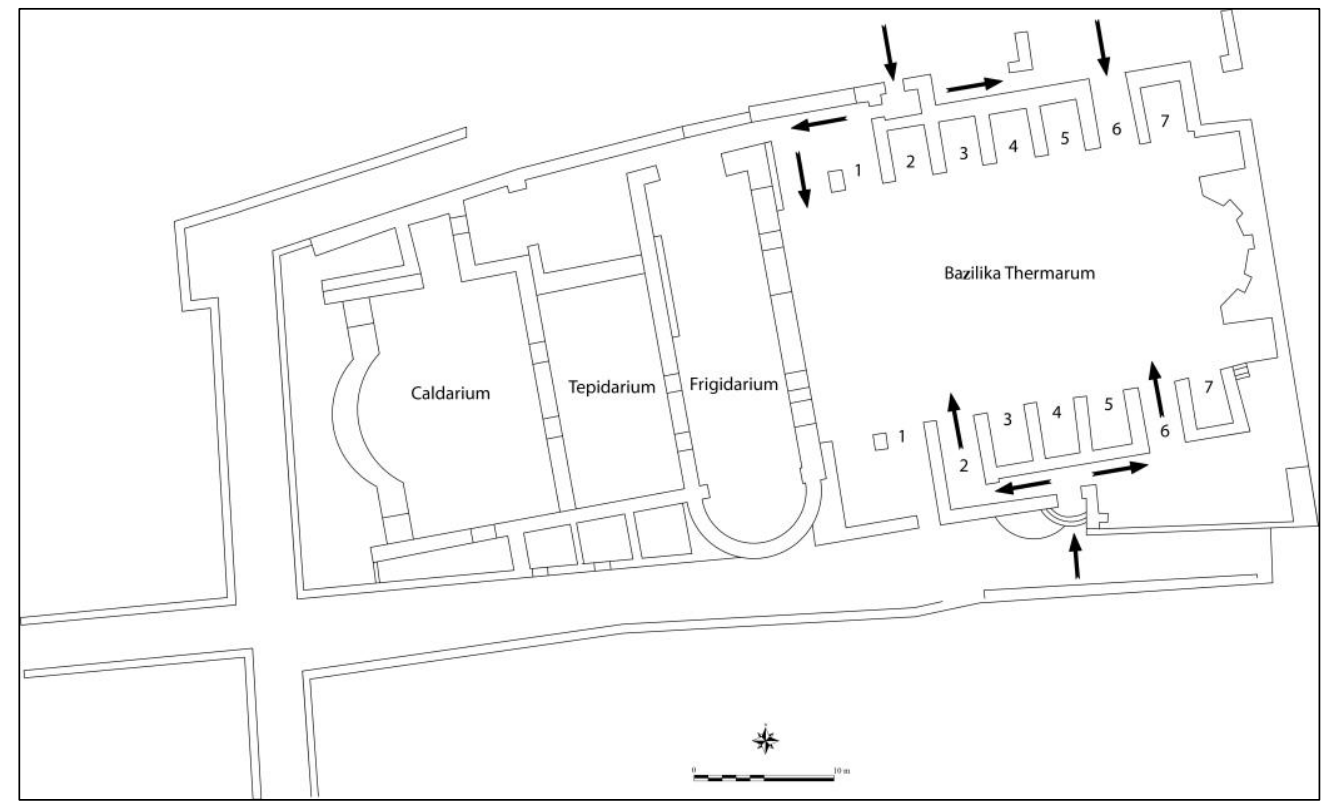

Fig. 14. Bazilika Thermarum-Girişler

Yapının toplam beş adet girişi bulunmaktadır. Girişlerin ilki güneydeki caddeden yarım daire biçimindeki bir merdivenle sağlanır. İkincisi yapının güneydoğu köşesindedir, geç bir evrede kapatılarak iptal edilmiştir. Bir diğer giriş kuzeydoğu cephede yer alır. Ama buradan önce yapının yan bölümlerine ulaşılır, sonra da asıl mekâna. İki adet giriş de kuzeydeki cadde üzerinden sağlanmaktadır (Fig. 14).

Kazılarda ele geçen mimari buluntular, derin nişlerin her birinin üzerinin tuğla örgülü bir beşik tonozla kapalı olduğunu göstermektedir. Bu oda-nişlerden karşılıklı iki adedi (6-6 numaralar) yapıya girişi sağlamaktadır. Apsisin güneyindeki niş içinde, güneyde üç basamağı korunmuş bir merdiven yer almaktadır. Nişlerin tam işlevlerini aydınlatacak verilere maalesef ulaşılamamıştır. Sadece 5. ve 7. nişler, girişlerinde $50 \mathrm{~cm}$. genişliğinde $35 \mathrm{~cm}$. yüksekliğinde, üzeri mermer

görüşler için bk. Erkoç - Koçak 2018, 103-114. 
kaplı birer eşiğe sahiplerdir ${ }^{26}$. Bu özellikleriyle diğerlerinden ayrılırlar.

Mermer zeminli apsiste $1.45 \times 1.20 \times 0.65 \mathrm{~m}$ ölçülerinde, biri tam merkezde diğerleri ise kuzeyde ve güneyde olmak üzere, üç adet küçük niş vardır. Bu nişler içerisinde büyük bir olasılıkla heykeller bulunmaktaydı.

Bazilika thermarum'un zemini mermer levhalarla döşenmişti. Döşemeden geriye sadece bir kaç noktada in situ parçalar ve harç yüzeyinde dikdörtgen levhaların izleri kalmıştır. Mekânın üst örtüsünün tuğla tonoz olduğu, kazılarda açığa çıkarılan ve ilerideki ziyaretçilerin yapıdaki tahribatın izlerini görebilmeleri için yerinde bırakılan devasa tonoz çöküntüsünden anlaşılmaktadır (Fig. 2).

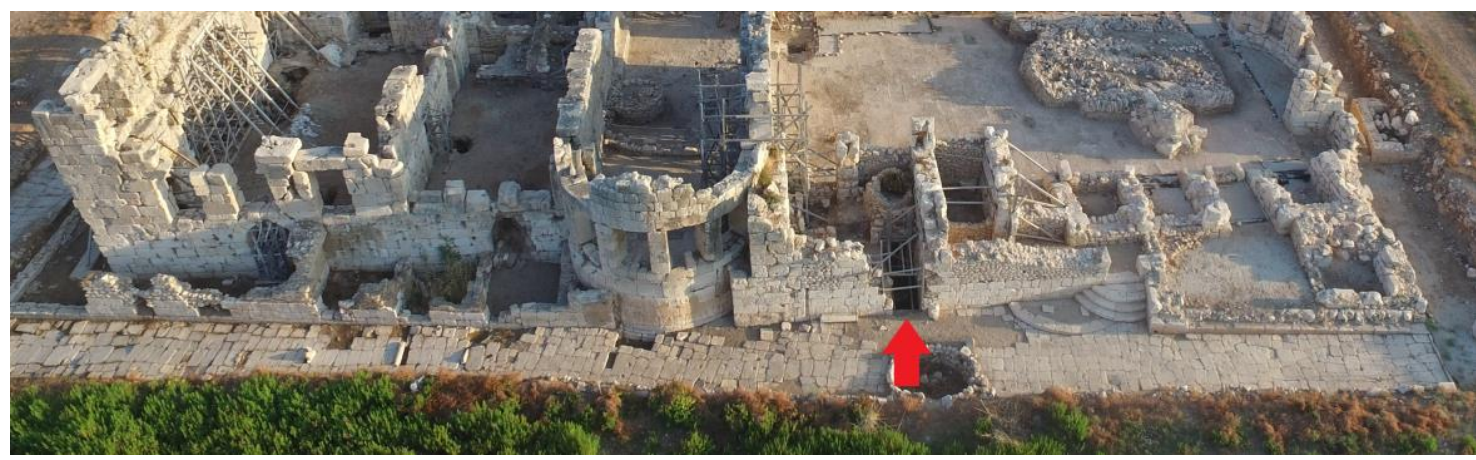

Fig. 15. Güney cephe-Tonozlu mekân

\section{Yapı kompleksinin batı, kuzey ve güney cepheleri}

Hamamın ana mekânları (frigidarium, tepidarium, caldarium) ile ona sonradan eklenen bazilika thermarum'un batı, kuzey ve güney cephelerinden birer cadde geçmektedir. Bu caddeler güneybatı köşede bir kavşakla birleşir. Kireçtaşı büyük bloklardan yapılmış, kenarlarında kaldırıma sahip bu caddeler, 2016 yılında gerçekleştirilen kazılar doğrultusunda bazilika thermarum'un yapıya eklendiği MS III. yüzyılın ortalarından önceki bir döneme ait olmalıdır. Doğu cephede mozaik döşemeli bir taban hemen duvara bitişik bir halde olup, doğudaki toprak kesitin altına doğru uzanmaktadır.

Yapı kompleksinin praefurnium’ları, caddeden görülmeyecek bir biçimde duvarlarla çevrilidir. Kuzeyde, caldarium'un kuzeybatısında kalın duvarlı dar bir koridor uzanır (Fig. 11). Bu koridor, kuzey praefurnium servis alanını batıdakiyle birleştirir. Duvarlarının kalın olması hem bazı bölümleri korunmuş beşik tonozu hem de -çok büyük bir olasılıkla- bu tonozun üzerine yerleştirilmiş bir su deposunu taşıma amaçlı olmalıdır. Söz konusu su deposuna ait arkeolojik izler duvarlardaki kalker kalıntılarından ibarettir. Batıda, toplam üç adet praefurnium içeren ve üzeri tonozla örtülü servis

26 Vedius Gymnasium'undaki (Ephesos) Mermer Salonun hemen arkasında "H" biçimli, bazilikayı andıran büyük bir mekân yer alır. M. Steskal ve M. La Torre bu mekânı bazilika thermarum olarak adlandırırlar. Burada da tıpkı Patara'da olduğu gibi derin oda nişler gözlemlenir. Bu nişlerde taştan banklara rastlanılmış olması, önceleri buraların apodyterium olarak isimlendirilmesine neden olmuştur. Ancak Steskal ve La Torre, bunların zeminlerinin ana mekândan yaklaşık $30 \mathrm{~cm}$ derinde olduklarını ve duvarlarındaki nişlerde de orijinal kullanım evrelerinde havuz ve çeşmelerin olduğunu belirtmişlerdir. Bundan hareketle de bu odaları, yazın serin kışın ise ılık olan bir tür su salonu ya da çeşmeli salon olarak adlandırmışlardır, bk. Steskal 2003, 235; Steskal - La Torre 2008, 298-299. Patara bazilika thermarum 'unda her iki yarıdaki 5 ve 7 numaralı nişler, ana mekânın zemininden yaklaşık $35 \mathrm{~cm}$ aşağıdadır. Ancak buralarda yapılan çalışmalarda Ephesos örneğinde olduğu gibi oturma banklarına ya da duvarlarında nişlere rastlanılmamıştır. Diğer taraftan sözü edilen bu mekânların duvarları iyi korunmamıştır; ayrıca orijinal kullanım evresinden sonra bunların tıpkı mekânın tamamında olduğu gibi yoğun bir biçimde işlik alanı olarak kullanılmış olması, belki de var olan izlerin de yok olmasına neden olmuş olabilir. 
alanından da güneydeki, yine tuğla tonoz örtülü servis alanına geçiş sağlanır. Bu servis alanı caldarium'un güney praefurnium'unu içerir. Bu son servis alanının doğusunda, her biri diğerinden bağımsız ve girişleri caddeden olmak üzere dört küçük mekân ardı ardına frigidarium apsisine kadar sıralanır. Bu mekânlardan sonuncusunun içinde, yukarıda değindiğimiz tepidarium'un sonradan açılan praefurnium'u vardır. Tüm bu mekânların üzeri tuğla tonozlarla örtülüdür.

Güney cephedeki en son unsur, frigidarium apsisi ile yarım daire merdivenin hemen hemen ortalarına denk gelen bir yerde yer alan kapıdır (Fig. 15). Bu kapıdan şu anda bir kaç basamağı görülen bir merdivenle cadde seviyesinin alt koduna ve aynı zamanda bazilika thermarum'un altına inildiği anlaşımaktadır. Girişin tavanı aşağı doğru daralan bir tuğla beşik tonozdur. Hem taban suyunun hem de statik riskler nedeniyle kazısı yapılamayan bu mekânın ne gibi bir işleve sahip olduğu maalesef bilinememektedir.

\section{Yapı evreleri}

En doğusunda, şimdilik nereye kadar uzandığını bilmediğimiz mozaikli bir zemin yer alan Liman Hamamı kompleksi en az dört büyük yapı evresine sahiptir. 2013 yılında Bazilika thermarum'da yapılan sondajlar, bu alanın hamama yaklaşık MS III. yüzyılın ortalarında eklenmiş olduğunu göstermiştir (Fig. 16-Kırmızı renk). 2016'da yapının özellikle ana mekânları ve çevresinde farklı noktalarında yapılan sondaj çalışmaları ise yapıda üç büyük yapı evresinin daha varlı̆ını tespit etmemize imkân sağlamıştır ${ }^{27}$.

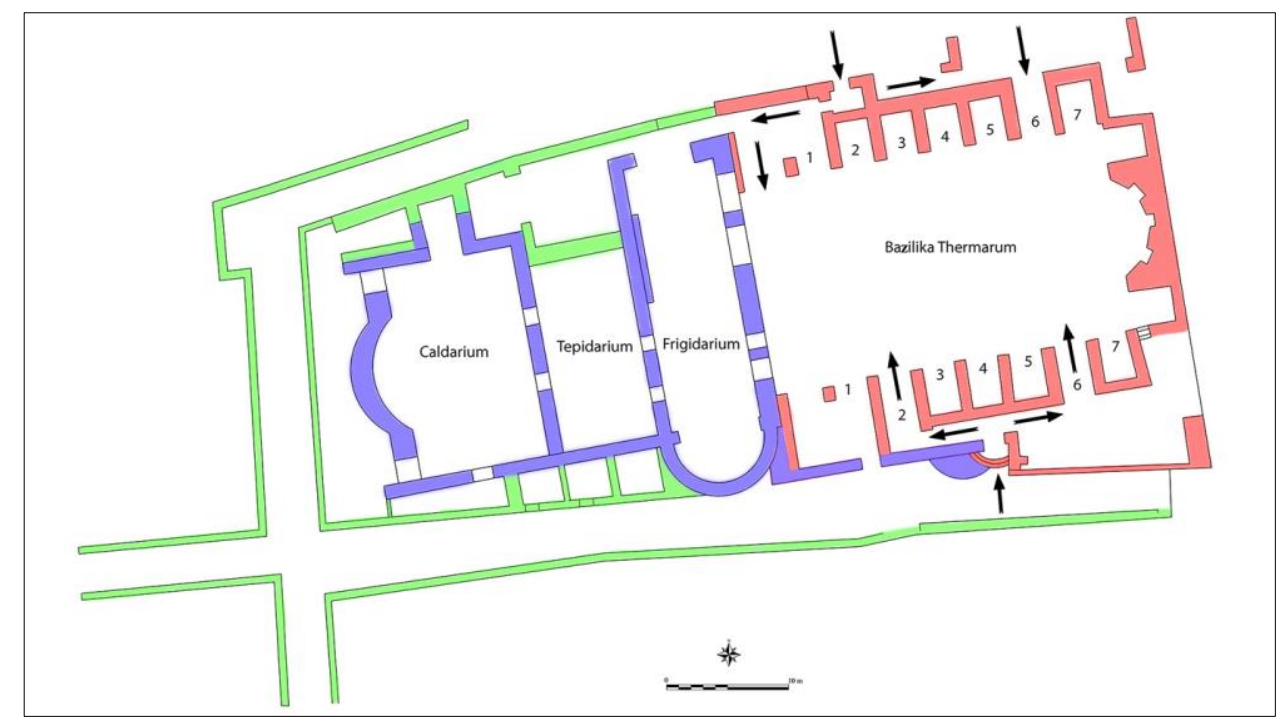

Fig. 16. Liman Hamamı Yapı evreleri

\subsection{Erken İmparatorluk Dönemi (Flaviuslar Dönemi)}

Kireçtaşı büyük blokların kullanılması ile inşa edilmiş, işçilik anlamında birbirleri ile benzerlikler sunan, duvarlar arasında organik bağlantıları tespit edilen ana mekânların (frigidarium, tepidarium ve caldarium) tarihlendirilmesine yönelik olarak caldarium'un batı cephesinde açılan sondajlardan (Sond.1-4/16) yapının temel basamağııı (+2.18 m) hemen üzerinden Erken Imparatorluk Dönemi'ne (Flaviuslar Dönemi) tarihlendirilen seramikler ele geçmiştir. Benzer tarihli bir bulgu tepidarium'un batı iç cephesinde açılan Sondaj $6 / 16^{\prime}$ da da tespit edilmiştir. Bu sondajda hypokaust sistemine ait tuğla payelerin oturtulduğu tuğla zeminin altındaki taş döşemeli alandan yine Flaviuslar Dönemi'ne tarihlendirilen seramik parçaları ele geçmiştir. Her

27 Erkoç et al. 2017, 132-134. 
iki alanda gözlemlenen Erken İmparatorluk Dönemi seramikler, ana mekânların yapımı için bir terminus post quem olarak kabul edilebilir.

Bu evrede hamam; kireçtaşı kesme blok taşlardan inşa edilmiş, üstleri küçük kırma taşların harç ile tutturulması ile oluşturulan tonoz ile örtülmüş, zeminleri ve iç duvarları mermer kaplı üç ana mekândan oluşmaktadır (Fig. 16-Mavi renk). Bunlar, daha önce de belirtildiği gibi, doğudan batıya frigidarium, tepidarium ve caldarium'dur. Ilk yapı evresinde bu üç mekânın bitişik çevresinde nasıl bir düzenleme olduğunu, arkeolojik bulguların yetersizliği nedeniyle, tüm ayrıntılarıyla bilememekteyiz. Örneğin, caldarium'u ve yıkanma için kullanılan suyu dıştan ısıtan praefurnium'ların ve yine bu amaç için kullanılan malzemenin (yakacak odun gibi) durduğu yerlerin kapalı bir servis mekânı içerisinde yer alıyor olması beklenmelidir. Ancak, ikinci yapı evresinde inşa edilen ve bu üç mekânı kuzey, batı ve güneyde çevreleyen duvarlar (Fig. 16-Yeşil renk) birinci evreye ait izleri tamamen yok etmiş olabilirler.

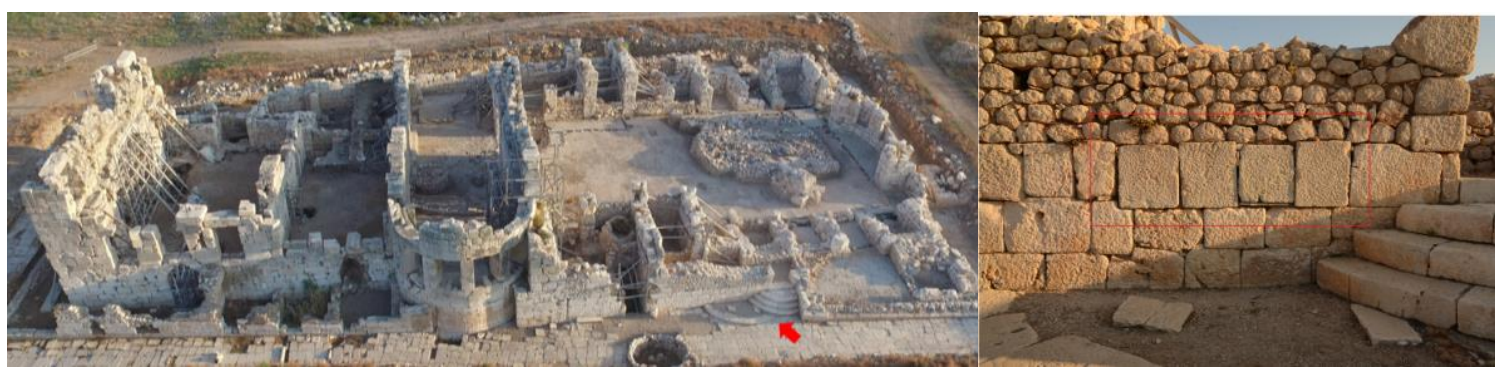

Fig. 17. Güney cephe-Merdivenler

Yapı kompleksinin doğusunda, sonradan üzerine bazilika thermarum inşa edilen bir "podyum" yer almaktaydı. Frigidarium'un önünden doğuya doğru uzanıyor ve bu yöne doğru yükselen arazideki kot farkını da kapatıyordu. Söz konusu bu -"podyum-"un yapının ilk evresine ait olduğunu gösteren iki adet kanıt vardır: 1. bazilika thermarum yapıldığında, yarım daire şeklindeki 4 basamaktan oluşan merdivenin üstten 3 basamağı doğuya doğru kaydırılmıştır. Geriye sadece en alt basamak kalmıştır. Bu en alt basamağın üzerinde yer alan eski girişin, çevresindekilerden biraz daha farklı kesimli kireç taşı bloklarla kapatılı̆̆ı rahatça görülebilir (Fig. 17). Bu girişin eşik yüksekliği de zaten merdivenin tamamının yüksekliğine eşittir. Bu girişin çevresindeki örgü özgün olup, bazilika thermarum'un yapıldığı döneme aittir. 2. frigidarium'un güneyindeki apsisi ile "podyumun" duvarlarının organik bir ilişki içinde oldukları görülür.

Yukarda kısaca tarif etmeye çalışığımız "podyumun" üzerinde, yani frigidarium'un doğusunda ne vardı sorusu şu an için cevaplanamamaktadır. Ama bu alanda, benzer hamam yapıları göz önünde bulundurulduğunda bir palaestranın yerleşik olma olasılığı yüksektir. Ayrıca, güneydeki caddeden bu podyumun altına inen galerimsi girişin bu ilk dönemden olup olmadığını da söylemek zordur. Çözüm ancak, taban suyu ve çökme tehlikesi nedeniyle gerçekleşemeyen kazıyla gelebilecektir.

\subsection{MS I. yüzyılın sonu - II. yüzyılın başı}

Ana mekânlardan frigidarium'un kuzeydoğu köşesinden başlayıp tepidarium ve caldarium boyunca devam eden, batı yüzü geçip tekrar doğuya yönelen ve frigidarumun apsisine dayanan duvarın ana mekânların duvarları ile organik herhangi bir bağlantısı yoktur (Fig. 16-Yeşil renk). Bu nedenle buraya ana mekânlardan (frigidarium, tepidarium, caldarium) daha geç bir dönemde eklenmiş olmalıdır ve yapıyı çevreleyen caddeler de yine bu yeni yapı programının bir ürünü olmalıdır. Frigidarium'un kuzeydoğu köşesinden başlayan kuzey duvarının iç ve dış cephesinde açılan sondajlarda duvara dair önemli bilgiler ele geçmiştir ${ }^{28}$.

28 Erkoç et al. 2017, 132-134. 


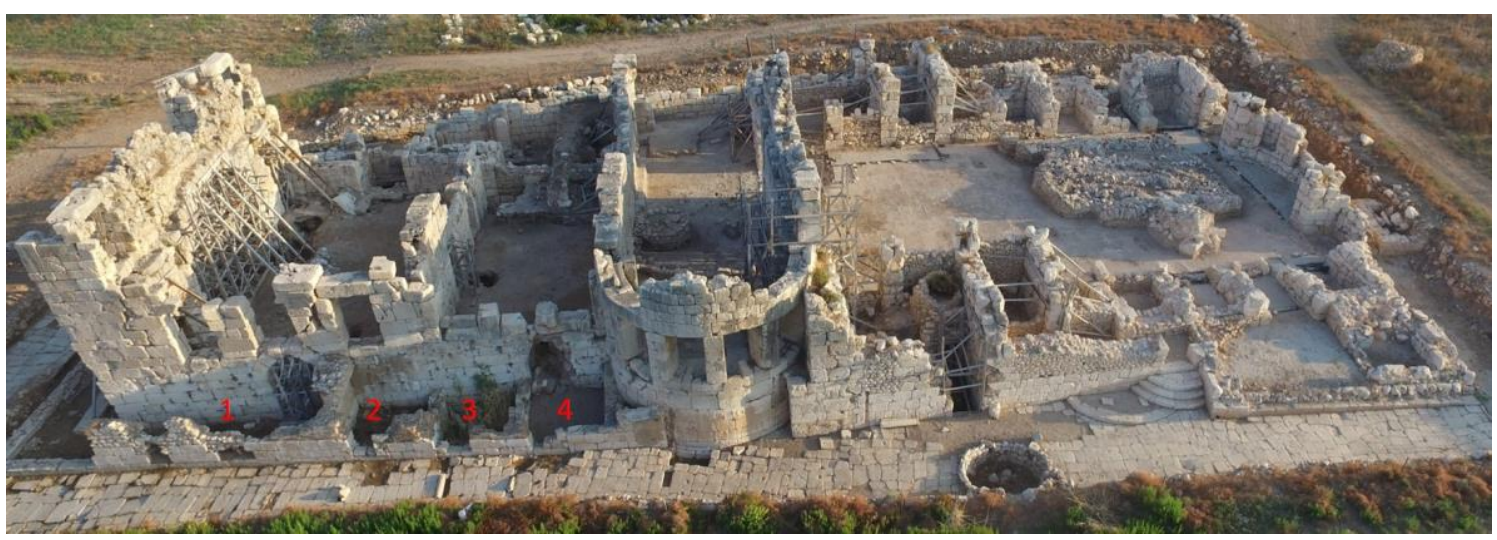

Fig. 18. Güneybatı köşe-Mekânlar

Mermer zemininin hemen altındaki tabaka içerisinden ele geçen seramiklerin ilk değerlendirmeleri zeminin MS I. yüzyılın sonu - en geç II. yüzyılın başında yapılmış olduğuna işaret etmektedir. Tespit edilen bu tarih, frigidarium'un kuzeydoğu köşesinden başlayıp tepidarium boyunca uzanan kuzey duvar için önemlidir. Zira frigidarium'un mermer zemini de olasılıkla kuzey duvarının buraya eklenmesi ve mekânın uzatılması ile bir düzenleme geçirmiştir. Bu evrede frigidarium'un kuzeydoğu köşesinden başlayıp caldarium'a oradan da frigidarium apsisine uzanan duvarlar, yeni mekânlar oluşturmuştur. Bunların en önemlisi şüphesiz sudatorium olarak adlandırdığımız mekândır. Caldarium'un kuzey, batı ve güney cephelerinde yukarıda değindiğimiz servis alanları ve yine güney cephedeki dört bağımsız mekân da yine bu dönemde oluşturulmuş olmalıdır (Fig. 18).

\subsection{MS III. yüzyıl ortası}

Hamamın çekirdek bölümünün (frigidarium, tepidarium, caldarium) doğusunda konumlanan ve bazilika thermarum olarak isimlendirilen mermer zeminli yapının duvarlarının çekirdek yapı ile organik bir bağlantı içerisinde olmaması, frigidarium apsisine ait bir pencerenin, buraya girişi sağlayan bir kemerin yarısının ve yine frigidarium duvarına ait bir konsolun iptal edilmeleri (Fig. 13); yine yukarıda bahsettiğimiz duvar örgü sistemlerindeki farklılıklar bu yapının hamamın doğusuna daha geç bir dönemde eklenmiş

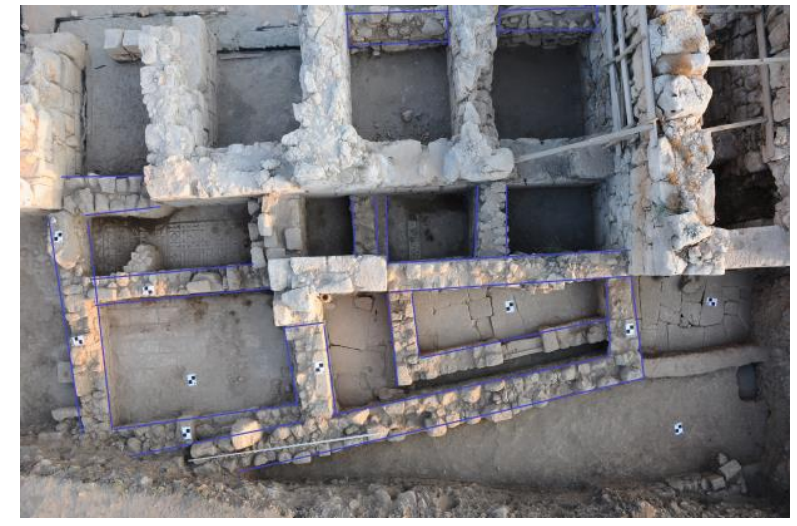

Fig. 19. Bazilika Thermarum Kuzeydoğu köşe-Mekânlar olduğunu göstermektedir. Yapılan sondajlardan ele geçen malzemelerin ilk değerlendirmeleri, bu eklemenin MS III. yüzyıl ortalarında olduğunu ortaya koymuştur (Fig. 16-Kırmızı renk). Bazilika termarum'un kuzeyindeki 4. derin nişin hemen arkasında ele geçen mozaik zemin üzerindeki yazıt da bu tarih ile uyumludur.

\subsection{MS IV./V. yüzyıI - VII. yüzyıl}

Hem ana mekânlar hem de bazilika thermarum'da gerçekleştirilen çalışmalar yapının MS IV. yüzyılın sonu-erken V. yüzyılda hamam olarak kullanımının sona erdiğini göstermiştir. Yapının neredeyse tüm mekânları bu tarihten MS VII. yüzyılın ilk yarısına kadar işlik alanı olarak kullanılmıştır ${ }^{29}$.

29 Hamamın batı ön cephesinde 1992 yılında gerçekleştirilen kazı çalışmalarında pithos biçimli bir fırın ile 


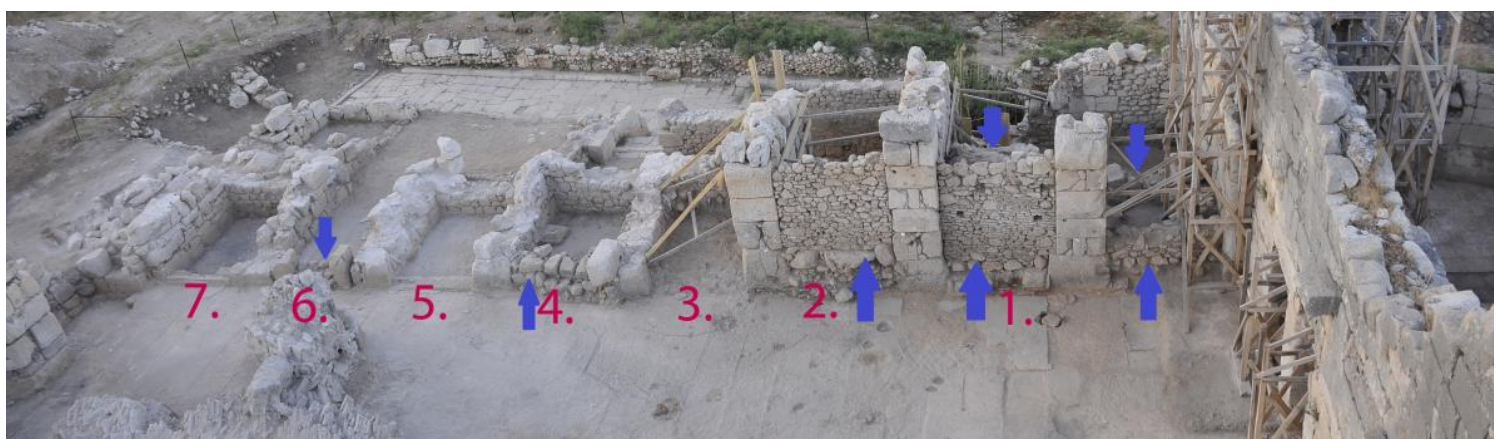

Fig. 20. Bazilika Thermarum-Güney'deki derin nişler

Özellikle batı cephede tespit edilmiş olan metal eritme fırını ve havuz da yine bu süreçle ilgilidir. Benzer buluntular hem frigidarium ve tepidarium'da hem de bazilika thermarum'da tarafımızca tespit edilmiştir. Özellikle bazilika thermarum'un kuzeydeki 1. nişin hemen önündeki kil dinlendirme havuzu (burada kil sucuklar ele geçmiştir), güneydeki 1. nişin içindeki iyi korunmuş durumdaki seramik fırını, ayrıca doğudaki apsidal duvar önünde açığa çıkarılan büyük boyutlu demir cürufları yine bu döneme ait önemli verilerdir. Frigidarium'un güney yarısında konumlanan temelsiz, tuğla kırıkları, moloz ve kesme taşların hiçbir bağlama unsuru olmaksızın bir araya getirilerek örülen apsidal ve doğu-batı uzantılı duvarlar, bu duvarların hemen kuzeyinde konumlanan yine tuğla kırıklarından meydana gelen yuvarlak formlu ocak; bazilika thermarum'un kuzeydoğusunda doğrudan mozaiklerin üzerine yine devşirme malzemeyle oluşturulmuş küçük mekânlar (Fig. 19-Mavi renk), bazilika thermarum'un güney ve kuzeyindeki derin nişlerin ortadaki mermer zeminli alana açılan kısımlarının küçük taşlarla örülerek kapatılması (Fig. 20), bu sürecin birer yansıması olmalıdır.

birlikte tezgâhı, duvara monte edilmiş çeşmesi ve havuzcuğu açığa çıkarılmıştır. Araştırmacıların etrafındaki buluntularla birlikte değerlendirdikleri bu fırının metal eşyaları eritmek amacı ile kullanım görmüş olduğu tespit edilmiştir. Ayrıca aynı cephenin güneyinde içinde seramik çamuru içeren bir kuyunun tespiti yakın bir noktada seramik işliğinin olabileceğini düşündürmüştür. Çalışmalar ile ilgili detaylı bilgi için bk. Bulba Kızgut 1995, 286-287; Kuzey cephedeki işliklerle ilgili olarak bk. Alanyalı 2009, 140-144. 


\section{BİBLIYOGRAFYA}

Abbasoğlu 1982

Alanyalı-Soykal - Şen 2007

Alanyalı 2009

Bulba - Kızgut 1995

Crema 1959

Çevik 1993

Çevik - Kızgut 1995

Erkoç - Akca 2012

Erkoç 2013

Erkoç 2014

Erkoç 2015

Erkoç - Koçak 2015

Erkoç - Aktaş 2016

Erkoç et al. 2017

Erkoç - Koçak 2018

Farrington - Coulton 1990

Farrington 1995

Gülşen 2007

Işık 1992

Işık 1999

Işık 2000

Kızgut - Özhanlı 1996
H. Abbasoğlu, Pamphylia Bölgesi Roma Devri Hamamları. Yayımlanmamış Doçentlik Tezi, İstanbul Üniversitesi. İstanbul 1982.

F. Soykal-Alanyalı - D. Şen, "Patara Hurmalık Hamamı Frigidariumu ve Seramiğin Stratigrafik Olarak Değerlendirilmesi”. Eds. B. Karasu - N. Ay - Z. Çobanlı - F. S. Alanyalı - R. Yamaçlı, SERES 2007, IV. Uluslararası Katıımlı Seramik, Cam, Emaye, Sir ve Boya Semineri, 26-28 Kasım 2007. İstanbul (2007) 412-430.

F. Alanyalı, "Patara Hurmalık Hamamı 2005-2008 Yılı Arkeoloji ve Belgeleme Çalışmalarına Genel Bir Bakış". Eds. A. Çabuk - F. Alanyalı, Kültür Varlıklarının Belgelenmesi. Eskişehir (2009) 117-144.

M. Bulba - i. Kızgut, "Liman Hamamı”. F. Işık, "Patara 1992". KST 15/2 (1995) 286-287.

L. Crema, "L'Architettura romana". Enciclopedia classica III, vol. 12.1. Turin (1959) 409.

N. Çevik, "Hurmalık". F. Işık, "Patara 1991". KST 14/2 (1993) 393-394.

N. Çevik - I. Kızgut, "Hurmalık Hamamı”. F. Işık, "Patara'93. KST 16/2 (1995) 255-256.

S. Akca - Erkoç, "Hurmalık/Liman Hamamı". H. İşkan-Işık, "Patara 2010 Yılı Kazı ve Restorasyon Çalışmaları". KST 33/3 (2012) 18-20.

S. Erkoç, "Hurmalık/Liman Hamamı ve Palaestrası". H. İşkan-ışı, "Patara 2011 Kazı ve Restorasyon Çalışmaları". KST 34/ 3 (2013) 173.

Erkoç, S., "Liman Hamamı Palaestra (?) Çalışmaları". H. İşkan et al., "Patara 2012 Yılı Kazı ve Koruma Çalışmaları". KST 35/ 2 (2014) 275.

S. Erkoç, "Liman Hamamı 2010-2013 Yılı Kazı Çalışmaları”. Eds. H. İşkan - F. Işık, Patara VII.1: Kum'dan Kent'e, Patara Kazılarının 25 Yılı Uluslararası Sempozyum Bildirileri, 11-13 Kasım 2013. İstanbul (2015) 239-251.

S. Erkoç - M. Koçak, "Liman (Hurmalık) Hamamı". Ş. Aktaş et al., "Patara 2014 Yılı Çalışmaları". ANMED, Anadolu Akdenizi Arkeoloji Haberleri 13 (2015) 97.

S. Erkoç - Ş. Aktaş, "Die Thermen". Eds. H. İşkan et al., Patara. Lykiens Tor zur römischen Welt. Mainz (2016) 63-68.

S. Erkoç - M. Koçak - S. Laetzer Lasar, "Liman Hamamı Çalışmaları". H. Işık, "Patara 2016 Kazı ve Koruma Çalışmaları". KST 39/2 (2017) 132-134.

S. Erkoç - M. Koçak, "Four Relief-Pedestals From Patara", SoSchrÖAl 56 (2018) 103-114.

A. Farrington - J. J. Coulton, "Terracotta Spacer Pins in Lycian Bath Buildings". AnatSt 40 (1990) 55-67.

A. Farrington, The Roman Baths of Lycia. London 1995.

F. F. Gülşen, "Patara'daki Roma Dönemi Hamamlarında Planlama ve Mimari”. Haz. B. Can - M. Işıklı, Atatürk Üniversitesi 50. Kuruluş Yıldönümü Arkeoloji Bölümü Armağanı, Doğudan Yükselen ışık Arkeoloji Yazıları. İstanbul (2007) 453-470.

F. Işık, "Patara 1990 Etkinlikleri”. KST 13/2 (1992) 235-258.

F. Işık, "Eine lykische Metropole erwacht aus ihrem "Dornröschenschlaf". AW 30/5 (1999) 477-493.

F. Işık, Patara. The History and Ruins of The Capital City of Lycian League. Antalya 2000.

i. Kızgut - M. Özhanlı, "Hurmalık Hamamı". F. Işık, "Patara 1994". KST 17/2 (1996) 165-166. 
Kızgut et al. 1997

Kızgut 1999

Korkut 2003

Korkut 2015a

Korkut 2015b

Maccanico 1963

Nielsen 1990

Steskal 2003

Steskal - La Torre 2008

Şen - Yıldırım 2012

Şimsek 2015

von Gerkan - Krischen 1928

Ward - Perkins 1981

Yegül 1992

Yegül 2006

\section{Serap ERKOÇ}

i. Kızgut - M. Özhanlı - ş. Aktaş - F. Gülşen, "Hurmalık Hamamı Kazısı". F. Işık, "Patara'95". KST 18/2 (1997) 199-200.

i. Kızgut, "Liman Hamamı”. F. Işık, "Patara 1997”. KST 20/2 (1999) 159-160.

T. Korkut, "Zur Iykischen Badearchitektur im Lichte der Thermen von Patara". IstMitt 53 (2003) 445-459.

T. Korkut, Akdağlar'ın Yamacında Bir Likya Kenti Tlos. İstanbul 2015.

T. Korkut, Arkeoloji, Epigrafi, Jeoloji, Doğal ve Kültürel Peyzaj Yapısıyla Tlos Antik Kenti ve Teritoryumu. Ankara 2015.

R. Maccanico, "Ginnasi Romani ad Efeso". ArchCl 15 (1963) 32-60.

I. Nielsen, Thermae et Balnea. The Architecture and Cultural History of Roman Public Baths. Aarhus 1990.

M. Steskal, "Bemerkungen zur Funktion der Palästren in den ephesischen Bad-Gymnasium-Kompleen”. Öjh 72 (2003) 227-239.

M. Steskal - M. La Torre, Das Vediusgymnasium in Ephesos. Archäologie und Baubefund. Wien 2008.

D. Şen - Yıldırım, "Hurmalık Hamamı Buluntuları Işığında Patara'nın Geç Roma-Erken Bizans Dönemi Kuzey Afrika Kökenli Seramikleri". Anadolu Üniversitesi Sosyal Bilimler Dergisi 12/4 (2012) 151-171.

C. Şimşek, Laodikeia Kilisesi. Lykos Vadisi'nde Hıristiyanlık. İstanbul 2015.

A. von Gerkan - F. Krischen, Thermen und Palästren, Milet 1.9. Berlin 1928.

J. B. Ward - Perkins, Roman Imperial Architecture. New York 1981.

F. K. Yegül, Baths and Bathing in Classical Antiquity. New York 1992.

F. K. Yegül, Antikçağda Hamamlar ve Yıkanma. Çev. E. Erten. İstanbul 2006. 